\title{
Public Debt
}

\begin{abstract}
More than a third of private wealth in the OECD plus China region consists of entitlements to public retirement benefits. If the state covered these future obligations using a reserve fund, an insoluble problem of investment would arise. It is only by doing without reserve funds that the twenty-first century welfare state is compatible with price stability at non-negative real interest rates. In calculating government obligations according to the ADL method, statistical offices acknowledge the implicit public debt deriving from the retirement system. Systems of public health insurance and public nursing care insurance also generate considerable implicit public debt and corresponding private wealth. The TRILL system advocated by Robert Shiller can make an important contribution to stabilize the high public debt that will be necessary in the future at low real interest rates. We undertake an empirical estimation of the level of public debt in the OECD plus China region. To determine explicit public debt, we use data on net public debt from the International Monetary Fund. Implicit public debt is mainly comprised of the state's capitalized financial obligations deriving from the public retirement system and public health insurance. Some statistical offices publish data on the retirement benefit entitlements that have accrued within social security systems. This data provides an important basis for our calculations. We estimate that total public debt in the OECD plus China region is equivalent to more than $600 \%$ of total annual consumption in the region.
\end{abstract}




\title{
6.1 Public Debt: Theoretical Foundations
}

\author{
Part 1: What Is Public Debt?
}

\subsubsection{Introduction}

Our objective is to estimate the size of the net private wealth of people in the OECD plus China region. A large part of this wealth consists of the state's future payment obligations vis-à-vis its citizens. We subtract from this the state's claims on its citizens in the form of a wide variety of loans. Our analysis is guided by the balance sheets that are commonly used in the private sector. Since we are treating the OECD plus China region as a closed economy (cf. Sect. 3.11), we can also say that we are preparing a consolidated balance sheet of all the citizens in this area and calculating the citizens' "equity" reflected in this balance sheet. As a mirror image of the latter, we are also compiling a consolidated balance sheet of the public sector in the OECD plus China region. This also includes para-governmental organizations (like, for instance, the insurance providers forming part of the public health insurance system in Germany). The resultant state equity — with the "state" being understood here as the collective of the individual national states in the region-is negative nowadays, since in the OECD countries plus China, public debt vis-à-vis citizens is, on average, greater than the sum of the state's real and financial assets.

This way of calculating net public debt is the equivalent of calculating wealth by the "Accrued-to-Date Liabilities" approach (ADL approach), which has also been employed in the official national accounts recently. This method will be presented in detail in Chap. 6.2. Roughly speaking, it corresponds to the accounting practices that are commonly used in the private sector. On this approach, welfare state obligations also form part of public debt. For analogous future obligations of a firm vis-à-vis its employees have to be recorded as liabilities in the balance sheet under the heading of "retirement provisions."

This accounting method is not the same thing as the forecasts that are made in connection with the concept of the "sustainability" of public finances. "Generational accounting," which was developed by Kotlikoff and applied to Europe by Raffelhüschen and others, is an example (Kotlikoff 1992; Raffelhüschen 1999). The analysis by Werding (2011), which was commissioned by the German Council of Economic Experts, and the Council report based on it (SVR 2011) follow a similar approach. The point of these studies is to juxtapose the state's future expenditure and revenue. The private sector analogy is a "business plan," not a balance sheet drawn up on a given date. Another way of recognizing the difference between the approaches is that the temporal horizon of the ADL method we use is finite, inasmuch as only the claims of current contributors and retirees are recorded. By contrast, generational accounting and sustainability analyses always depend on taking all future generations into account. Hence, they have an "infinite" time horizon. Since, however, they ultimately have to employ finite values, they only 
work if the discount rate used is greater than the growth rate of the economy in question. These methods have then to rule out in advance that there can be an interest rate that remains lower than the growth rate in the long run. They are thus not appropriate for our purposes.

But as a solvent borrower that, as experience shows, has privileged access to the capital market, how is it possible for the state to have negative equity? The explanation is the state's monopoly on the use of violence. Thanks to a sort of "quasi-mortgaging" of future tax revenue, the latter allows the state to convince the capital market that public debt will be serviced. The citizen's ability to enjoy wealth that is perhaps twice national wealth per capita presupposes that Hobbes's idea of the Leviathan is correct: Only the state can legitimately use violence. And as collector of taxes, the state demands obedience from citizens: demands that taxes are in fact paid. (For more on this, cf. Sect. 5.1.4.)

\subsubsection{Explicit Net Public Debt}

In Sect. 6.2.1, we present the size of the explicit net public debt of the OECD plus China region. It comprises around three-quarters of the annual consumption of the area as a whole. But there are, of course, significant differences from one country to another. We will not go into their causes here. We will come back to them in the policy-oriented second part of this book: in particular, in Chaps. 10 and 11.

When interest rates are high, explicit public debt gives rise to a significant fiscal burden. If, however, interest rates are persistently lower than the economy's growth rate, no positive primary surplus is required to hold the public debt ratio constant. The analytical details were presented in Chap. 2.

Explicit public debt represents wealth for citizens: and indeed liquid wealth — at least in normal times. In Sect. 5.1.12, we showed that as a component of wealth, public debt is also in a sort of competitive relationship with land and that this relationship has interesting distributive repercussions.

\subsubsection{Implicit Public Debt 1: Social Security Retirement Benefits}

We estimate that at least one third of private wealth consists of implicit public debt in the OECD plus China region. This means that this considerable share of total wealth is included in the official national accounts neither as wealth nor as public debt. The state's obligations to pay social security retirement benefits represent the most significant part of implicit public debt. How we calculate these obligations is different from how we calculate explicit public debt. But this difference is no reason not to recognize that the modern welfare state creates obligations for the state to pay out considerable sums in the future and that for the beneficiaries, on the other hand, these sums already represent "wealth" today. How they currently live their lives is strongly influenced by the size and security of the entitlements that they have 
already earned in the context of the social security system. For workers who are covered by social security, the resulting entitlements have much the same effect on their saving and consumption behavior as pension claims that have, however, to be paid by a private person or a private business. But the latter claims undoubtedly form part of the assets of the beneficiaries, corresponding to liabilities of the same amount for the party required to pay them. Hence, analogously, the state's obligations resulting from social security should likewise be seen as liabilities.

In the introduction to this book in Chap. 1, we already noted that those entitled to future social security retirement benefits behave as if these future claims were wealth when making their saving and consumption decisions. The balance they strike between current consumption and voluntary current saving is such that without the future retirement benefits, many of them would fall into poverty in old age. The debates about retirement benefits and the threat of seniors living in poverty only make sense if we regard the expected benefits as something comparable to savings deposits or stock ownership. Hence, an economic approach requires us to treat these entitlements as wealth-just as Germany's constitutional court, the Bundesverfassungsgericht, has done.

The form taken by the state's obligation to pay social security retirement benefits is different than that involved in government bonds with a fixed-rate coupon. It has a greater resemblance to a private life annuity. But, exactly like fixed-rate bonds, the latter constitutes wealth for the beneficiary and a liability for the insurer. Hence, the different form taken by the state's obligations to pay retirement benefits is no reason for us not to recognize them as a part of public debt.

However, the payment of future social security retirement benefits - just like in the case of a private life annuity-is only an obligation to the extent that the required contributions have been paid into the social security system up to the date on which the balance sheet is compiled. Thus, the claims of people who are starting out in their careers, and have only just begun to pay into social security, are zero. If today they stop paying into the system, they have no claims to retirement benefits. By contrast, an employee who has been earning a salary for 45 years and now retires has claims to retirement benefits whose capitalized value comes to several times the value of his or her annual salary. The state-in particular, the social security retirement fund - owes him or her this amount. Hence, the latter should be considered as part of the stock variable "public debt."

An additional factor has to be taken into account when calculating this value. In most OECD member states, retirement benefits are continually adjusted to average wages. This is, in particular, a kind of protection against inflation, and it works as long as the evolution of nominal wages runs parallel to that of the price level. But, apart from this protection against inflation, there is also an adjustment - whose form varies from country to country and that is often only partial - to average real wages. Germany's "dynamic retirement benefits," which were first introduced in West Germany in 1958, are an example. The present value of these expected future adjustments to retirement benefits is, on average, considerable, because some of the claims they affect are far in the future and hence will undergo many such adjustments. 
Claims to social security retirement benefits thus bear a certain resemblance to the "TRILLS" that have been proposed by Robert Shiller and others for explicit public debt (Shiller and Kamstra 2010). Shiller proposes that the government issue securities whose holders will every year receive one-trillionth of the previous year's national product. These securities would be negotiable, and hence, their market value would be determined by supply and demand. The name "TRILLS" comes from "trillion" and rhymes, moreover, with "bills": hence, Robert Shiller's call for "TRILLS instead of T-bills." A major difference between TRILLS and claims to social security retirement benefits is, of course, that the latter come to an end with the death of the beneficiary, whereas the claim to TRILL-income is transferable and inheritable. We will come back to the TRILLS in greater detail in a section especially devoted to them below.

There is, of course, another significant difference between claims to social security retirement benefits and traditional government bonds. Claims to retirement benefits either are non-negotiable or can only be transferred with great difficulty. In keeping with the very idea of social security, they represent a kind of "forced saving." They are also supposed to prevent workers from becoming dependent on public assistance once they stop working, due to insufficient voluntary saving. It would be incompatible with this function, if claims to social security retirement benefits were negotiable like ordinary securities.

Social security was initially conceived and also implemented (on the model of private insurance) with a reserve fund, which was supposed to cover payment obligations as they come due. If it had endured, such a funded scheme would have been a form of social security that did not increase net public debt. Like it or not, when the reserve fund disappeared in Germany due to the war and the resulting inflation, a transition had to be made to a so-called pay-as-you-go system, in which current retirement benefits are principally paid using the contributions of active members and their employers. In the meanwhile, however, the system also receives considerable subsidies from the federal budget. A "pay-as-you-go" system can be understood as a sort of funded social security minus the reserve fund, which is precisely lacking here. This makes it particularly clear that the state's obligations to pay future retirement benefits are a form of public debt. The considerations developed here on the basis of the German example essentially apply for all OECD countries, although there are, of course, quantitative differences from one country to another.

\subsubsection{Implicit Public Debt 2: Public Health Insurance}

To the implicit public debt resulting from the social security retirement plan, we have also to add the implicit public debt resulting from public health insurance. In Germany, most employees and employers make contributions to public health insurance that are only slightly less than their contributions to the public retirement plan. These contributions finance a large part of the healthcare system, whose services are provided to members of the public healthcare plan free-of-charge in the 
overwhelming majority of cases. Since the contributions are proportionate to the gross wages of beneficiaries, public health insurance is not in fact insurance: The contributions are more like taxes. De facto, they are a kind of second income tax. The "tax revenue" from this second incomes tax is, however, tied to a particular purpose, since it can be used only for funding the healthcare system. The level of the contributions is determined such that they can cover the healthcare costs of all members of the public health insurance plan. Now, for both public and private health insurance, healthcare costs rise with the increasing age of beneficiaries. On the other hand, the contributions paid by beneficiaries - since they are proportionate to their wage income or, respectively, their social security retirement benefits - are, on average, higher for younger, still economically active beneficiaries than for retirees. Consequently, every public health insurance plan involves a considerable transfer of resources from young to old. In Germany, we could, in principle, calculate the size of this transfer for every insurance provider or Krankenkasse forming part of the public health insurance system.

On closer inspection, however, this "transfer" from one population group to another is in fact something else. It is rather a particular form of forced saving. A comparison with private health insurance makes this clear.

Private insurance providers "smooth" their premiums by collecting premiums from younger age cohorts that are greater than the costs to which they give rise and collecting premiums from older age cohorts that are not sufficient to cover their healthcare costs. But the private insurers are required to invest the surpluses that they generate from younger beneficiaries on the capital market and to form client-specific old-age provisions. These resources are then used to finance a discount in the form of a reduced premium for these same beneficiaries, so that premium payments are more evenly distributed over the course of a lifetime than would correspond to the costs incurred. Hence, a part of the premiums paid by younger beneficiaries serves as saving for their old age.

Private health insurance providers are thus in debt to their clients for the amount of the old-age provisions they form. In their case, however, these old-age provisions correspond to the resources they have invested on the capital market. In the same way, the public health insurance system is in debt to its younger beneficiaries, who are required to pay premiums greater than the costs to which they give rise, but who thus can count on having their healthcare costs taken care of in their old age, even though their contributions will then, on average, be insufficient to cover these costs. In this sense, the state is in debt to citizens enrolled in public health insurance-just as private insurance providers are in debt to their clients for the amount of their old-age provisions.

The only difference is that the public insurance providers do not form any reserve funds to cover these debts - and they also do not include any corresponding provisions in their balance sheets. This missing reserve fund thus corresponds to additional public debt of the same amount - exactly like the missing reserve fund in the case of the public retirement plan.

Entirely analogous considerations also apply for public nursing care insurance. The latter is also taken into account in our calculations in Sect. 6.2.2. 


\subsubsection{Implicit Public Debt 3: An Exotic Example in the Form of Germany's Renewable Energy Act}

It is not possible for us to count all implicit public debt. We concentrate here on the three most significant items: the public retirement plan, public health insurance and nursing care insurance. Similar institutions exist in almost all the member states of the OECD and are starting to develop also in China.

We want to mention just one exotic example of implicit public debt that is peculiar to Germany, in order to make clear to the reader how it is possible to find implicit public debt in many different forms. This exotic example will not be included in our calculation for the OECD plus China region as a whole, however. We are talking about Germany's Renewable Energy Act or EEG (Erneuerbare Energiengesetz). Like in the case of public health insurance, the Renewable Energy Act also involves a tax-like charge that is also connected to hidden public debt. This charge is a kind of "electricity tax," to which practically every consumer of electricity is subject in proportion to his or her usage.

The law promotes certain investments in electricity production that would not be profitable without subsidies and hence would not take place. The purpose of the legislation is to create incentives for an energy transition: a shift away from fossil fuels and toward renewable energies. A private investor who builds a wind park or a solar energy installation does not only receive priority rights to feed the produced electricity into the grid: For a period of 20 years, the investor also receives compensation per kilowatt-hour that is fixed by the state and that is significantly higher than the wholesale price of electricity that gets established every day on the energy exchange. But the burden of paying this additional compensation is not ultimately borne by the grid operator to whom the electricity is supplied. Rather, the grid operators are themselves compensated for buying the electricity at an elevated price, inasmuch as the price that end-users pay to them includes a surcharge on every kilowatt-hour consumed.

This web of payments within the framework of the EEG occurs entirely outside of the public budget, and hence, according to the official statistics, it also does not form part of the public sector share in the national product. Nonetheless, this should not obscure the fact that, from an economic point of view, the EEG surcharge is nothing other than a tax: in effect, an "electricity tax." For the EEG arrangement is economically no different than a hypothetical arrangement that would work by way of the budget. In this hypothetical alternative arrangement, the government imposes an electricity tax. This tax is always set such that it is just enough to finance the subsidies that the government provides to operators of wind and solar energy installations by paying a fixed price per kilowatt-hour for the electricity they supply for 20 years after the installations first come into operation.

The obligations vis-à-vis the owners of wind and solar energy installations that are assumed by the government in this alternative arrangement are comparable to the obligations that, as discussed above, the government assumes for the old age of beneficiaries covered by public health insurance. The fact that Germany chose a 
mechanism, in the form of the EEG, that takes place outside of the public budget is no reason not to speak here of implicit public debt.

The EEG has achieved its goal of establishing massive incentives for investment in wind and solar energy installations, and these incentives have also been extensively acted upon. Investment has been triggered. Exactly as in the case of debt-financed public investment, this investment can be financed by loans.

The amount of the public debt that is hidden behind the EEG can be estimated as follows. The investor in a wind park or a photovoltaic power station receives a share of the electricity tax for 20 years. In exchange, at time zero, he or she has made an investment of a certain sum. At the outset, the present value of the expected income from the electricity tax is thus (on a rough calculation that ignores interest rate effects) 20 times the annual income from the electricity tax. This value then declines over time, in more or less linear fashion, until it reaches zero in year 20. The average present value over time is thus ten times the annual income from the electricity tax, and public debt vis-à-vis this investor is also, on average, ten times the annual income from the electricity tax. If we add up the debt from all the energy installations that have been subsidized under the EEG in this way, then we obtain a figure for EEG-induced implicit public debt in the hundreds of billions.

\subsubsection{Public Debt When the Real Interest Rate Is Zero}

In Sect. 6.2.2, we arrive at an estimate of the size of implicit public debt. Our point of departure is the calculation of the present value of entitlements to social security retirement benefits. Each European Union member state calculates the present value of entitlements, and these national figures are published by Eurostat, the statistical office of the European Union. In accordance with uniform requirements, these present values are calculated at a real interest rate of $2 \%$ per year, $3 \%$ per year and $4 \%$ per year by discounting the future benefit payments.

The interest rate sensitivity of a stock variable like retirement benefit entitlements is great, since what is involved is the adding-up of future payments that are spread out over decades. This raises the question of the appropriate discount rate to use. For our purposes, there is a clear answer. Our analysis is based on the hypothesis that the natural rate of interest is negative in the twenty-first century. This means that positive net public debt is indispensable, if we want to achieve a non-negative real interest rate that is compatible with full employment.

In this context, it is interesting to know how great the share of net public debt is, when the real interest rate reaches its lowest possible non-negative level. Hence, we ask: How great is the present value of future claims to social security retirement benefits (and of analogous public health insurance and nursing care insurance claims), if we work with a real interest rate of zero?

We can also put this another way: If someone was to claim that a non-negative real interest rate is sufficient to satisfy people's saving requirements simply through the formation of private real assets, then he or she would have to show what is to be done with the money forming the hypothetical reserve fund for current public debt 
that is available at the lowest possible non-negative real interest rate-hence at the interest rate that is most favorable for this claim. At a hypothetical real interest rate of zero, however, this hypothetical reserve fund is the net public debt. This hypothetical reserve fund is the explanatory hurdle that anyone doubting our thesis has to overcome.

Moreover, the real interest rates at which countries with the highest possible credit rating can borrow have not in fact been higher than zero for quite some time already. The European calculations at a real interest rate of $3 \%$ or $2 \%$ per year are based on long-term averages. There is reason to think that the discount rates will be set lower in the future.

The leveraging effect of the discount rate on the present value can be identified with the average amount of time separating the payment obligations from the present. If this average time gap is 28 years, for example, then the present value of the total flow of these payment obligations increases by $28 \%$ with a reduction of the discount rate from 3 to $2 \%$ per year. The procedure employed for converting from present values at $2 \%$ per year to present values at zero percent per year will be explained in a methodological excursus in Sect. 6.2.2.1.

At a discount rate of zero percent, the present value of entitlements to social security retirement benefits for the OECD plus China region comes to nearly five times annual consumption. An estimated present value of the "savings" involved in public health and nursing care insurance of more than half of annual consumption has to be added to this.

In this calculation with a real interest rate of zero, explicit net public debt is only the "tip of the iceberg," representing around one-eighth or approximately $12.5 \%$ of total net public debt. (The visible tip of an iceberg in the North Sea accounts for around $11 \%$ of the iceberg's total mass.)

\section{Part 2: High Public Debt as a Problem for Stability}

\subsubsection{The Discounting Discrepancy Problem}

A little over a decade ago, Reinhart and Rogoff's This Time is Different came out (Reinhart and Rogoff 2009). Their book is about the large number of historically demonstrated debt crises that have occurred in the past. Again and again, powerful states have had to admit their inability to repay their debts and pay the interest on them. Again and again, the creditors have had to write off their claims as uncollectible. As the title of the book suggests, again and again, creditors have fallen for the assurances of loan-seeking governments that this time the new debt will certainly be paid back.

Twice in the twentieth century, Germany also failed to repay its debt. Once, creditors were expropriated by the Great Inflation from 1921 to 1923; the second time, the old currency had to be replaced by a new one, the Deutschmark, in order to restore orderly monetary conditions. This change of currency also amounted to a debt cancelation, as a consequence of which the state's creditors were largely expropriated. 
Our aim here is not to investigate why countries have so often defaulted on their debt. What we want to examine are the conditions of a functioning global capital market in a world in which substantial public debt is required, because privately desired wealth is far greater than the level of real assets that it is reasonable to maintain, i.e., since they can be productively used: in a world, in other words, in which people's desired waiting period $Z$ is far greater than the productively usable period of production $T$ plus the present value of land rents $l \omega$-even when the interest $r$ is zero.

Firstly, we can note that at a very low real interest rate that is close to zero, the primary surplus needed for stabilizing the public debt ratio $D$ is negative, since, in this case, the steady-state growth rate of the economy is greater than the rate of interest the government has to be pay. At a constant public debt ratio, net borrowing is greater than the government's interest payments. We have discussed this in detail in Chap. 2.

Now, this condition applies when the capital market is willing to lend money to the government without a risk premium. If the capital market demanded a risk premium, then the interest rate the government has to pay could be greater than the sustainable long-term growth rate of the economy. To this extent, the inequality $g>r$ discussed above in fact merely says the following:

Public debt can be serviced without difficulty, if the capital market believes that a country can service its public debt without difficulty.

Hence, we have to investigate what conditions are required, such that a country does not have to pay any risk premium or only has to pay a very low one.

We can assume that a country normally has an interest in being regarded as a reliable borrower on the capital market. A good reputation is important to its fiscal authorities. A country pays to have its outstanding debt rated by rating agencies. Inasmuch as the creditor (often a bank) wants to use government bonds as collateral for its own borrowing (e.g., from the central bank), it is usually obligatory to have them rated by rating agencies.

On the other hand, we have to keep in mind that a country's politicians in the legislature and the executive branch are under pressure to be able to show results in the very short term. Their reelection depends on it. But this means that the subjective discount rate on which politicians base their decisions is far higher than the risk-free capital market interest rate. This discounting discrepancy can give rise to problems for a country's reputation on the capital market.

Some countries have adopted measures against this discounting discrepancy. Thus, the bicameral system in the 1788 US constitution can already be seen as basically an institution that was meant to address the problem of politicians' high subjective discount rates. Although the House of Representatives is elected every two years, members of the Senate are elected for six years. The principle of an independent central bank also serves to ensure that monetary policy is not abandoned to the short-term goal of a quick-fix economic stimulus at the expense of long-term monetary stability. Finally, "debt brakes," such as those found in the 
Swiss or the German constitution, are institutional measures for hindering political decisions that favor short-term results to the detriment of long-term success. This sort of politics is often described as "populism" nowadays.

The theory of the negative natural rate of interest presented in this book and the consequent necessity of public debt make it more difficult to develop institutional measures for overcoming the discounting discrepancy problem. For simple constitutional rules, like the German and Swiss debt brakes, no longer work in a world with a negative natural rate of interest. Another way of putting this is that we can observe a secular trend toward a growing discounting discrepancy. Because people are living longer and longer and more and more people also want to leave large parts of their wealth as an inheritance, people's effective subjective discount rate has become smaller and smaller - or has even, as it were, become "negative." (We will dispense with formalizing this conclusion here.) At the same time, however, high subjective discount rates in politics represent just as big of a problem today as they were in the past. For their own private well-being and for the well-being of their descendants, people think in the long term, and this long term is getting longer and longer; but political institutions force politicians to act in a way that is just as short-term-oriented as in the past.

\subsubsection{The Relative Size of the Public Sector}

We will discuss the welfare state at length in Chap. 9 on the need for monetary stability. Our essential point will be that, in order to fulfill its social functions, the welfare state should not be too small, but, in the interest of preserving a liberal-democratic order, it also must not be oversized. There should be redistribution within the framework of the welfare state and a progressive income tax system; but it must not go so far as massively to undermine the incentive to contribute to the creation of the national product.

Here, we have now to examine a requirement for stability that is imposed by the international capital market. This requirement is closely connected to the question of the right size of the welfare state. This relationship is all the more important, the greater the public debt ratio $D$ required to satisfy the population's desired wealth.

Every economist is familiar with the "Laffer curve," which was named after an adviser to the former US President Ronald Reagan. Arthur Laffer used his ideas to justify the massive tax cuts that were characteristic of the Reagan era (Fig. 6.1).

At low tax rates, a country's fiscal authorities can count on tax revenue rising with a moderate increase in tax rates. At very high tax rates, a further increase in tax rates is counterproductive for tax revenue in the long run, since economic incentives decline so much that, in percentage terms, the tax base shrinks more than the average tax rates have risen. When tax rates are too high, the allocation of resources is so heavily distorted that the steering function of relative prices is excessively impeded.

At given tax rates, the state can increase its tax revenue by greater surveillance of its citizens. Thus, for example, the system of surveillance that is currently being implemented in China can be expected to lead to an obedience toward the authorities that will also bring about increased tax revenue. In every country, there is, in 


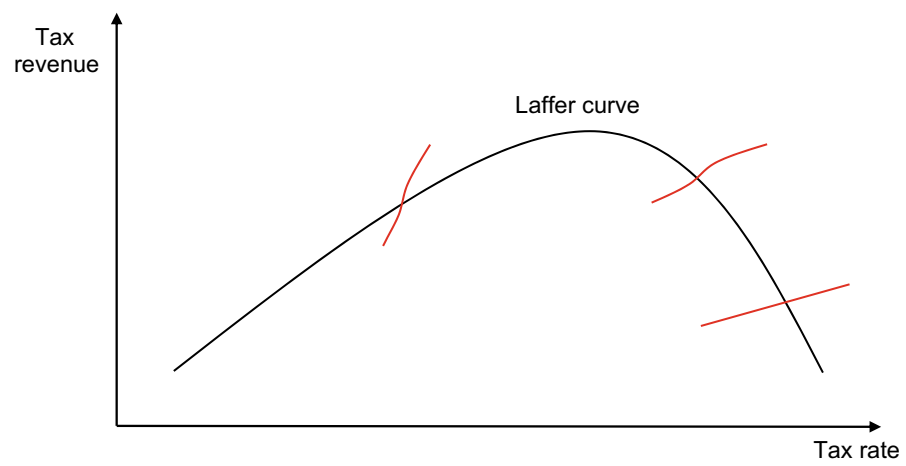

Fig. 6.1 Laffer curve. Source Authors' own presentation. Notes Black line: relationship between tax rate and tax revenue (long-term); Red lines: relationship between tax rate and tax revenue (short-term)

principle, a trade-off between privacy and the fiscal yield of the tax system. More "1984" creates higher government revenue. Better anti-corruption measures are one way in which stricter government surveillance can be brought about. More powerful tools of government surveillance can also be used to reduce crime. Less crime increases the efficiency of the economic system and hence also the yield of the tax system. This is not the place, however, for a detailed analysis of these relationships.

The Laffer curve is of significance for our analysis of public debt, because it also entails a relationship between the stability of public finances and the relative size of the public sector. In order to present this relationship, we have to distinguish between the short-term and long-term impact of changes in tax rates. As long as the economy has not yet adjusted to a tax increase, tax revenue will usually rise and net borrowing will fall commensurately. We speak here of the short-term impact of tax rate changes. The short-term impact of tax cuts is a decline in tax revenue and an increase in net borrowing.

As already discussed above, what ultimately determines the overall impact of tax rate changes on tax revenue is how economic actors adjust their behavior in response to them. These adjustments take place over a longer period of time. Whether the long-term impact of a tax increase on tax revenue is positive or negative depends on whether taxes were low or high before. If taxes were previously low, a modest increase in taxes can increase tax revenue. If taxes were previously high, a modest tax cut can-not right away, but in the long run-increase tax revenue.

As long as the tax burden of economic actors is low, a country's fiscal authorities can convince the capital market that public debt is a risk-free investment. For in the event of a shock that drives interest rates upwards, the fiscal authorities can increase tax revenue not only in the short term, but also in the long term, by increasing taxes. They are thus well-equipped for an interest rate shock. But other kinds of shock, which have a negative impact on tax revenue or require increased public spending, can also be cushioned by raising taxes, since doing so increases tax revenue not only immediately, but also in the long run. 
The situation is different, if taxes are so high that the top of the Laffer curve has already been passed. Here, it would be a good idea, in any case, to cut taxes. But the adoption of such a policy could be hindered by the short-term orientation of the political instances, as well as by the capital market. For, in the short term, the fiscal authorities would have to accept higher net borrowing. This, however, could be misinterpreted by the capital market as indicating a danger that outstanding bonds and loans may not be repaid. In addition, some of a country's citizens who are dependent on welfare benefits could interpret a tax cut as a redistribution from the poor to the rich-with the consequence that the government refrains from undertaking one (Uhlig and Trabandt 2011). But, in this case, the capital market would be right to demand a risk premium on government bonds.

There is, therefore, a causal relationship between how much wealth is redistributed via taxes and charges and the risk premium on outstanding government bonds.

The upshot of this analysis is that the share of national product represented by distorting taxes and charges must not be too great. An oversized welfare state has such a powerfully distorting effect on the price system and the system of economic incentives that it corresponds to a point on the descending part of the Laffer curve. But, if this is the case, then a country's fiscal authorities have to accept that they can only place its government bonds on the capital market with a considerable risk premium.

Thus we can ask, for example, whether the relative size of the public sector in France is not already beyond the maximum of the French Laffer curve. The country could, however, have massive difficulties, if its government tried to improve the situation by cutting taxes. For, in the short-term, this would lead to net borrowing that massively exceeds the Maastricht criterion. The Maastricht straitjacket would thus represent an obstacle to French economic recovery.

The considerations presented here would be irrelevant, if the public debt ratio was very small. For, in that case, shocks that raise the interest rate for government bonds would not be a problem for the capital market. But if, for the reasons discussed in Chap. 3 on desired wealth, the public debt ratio is high and its tendency is rising, then these considerations are extremely relevant. The interdependence between the level of desired wealth and the extent of reasonable redistribution within the framework of the welfare state has to be kept in mind.

\subsubsection{Refining the Concept of the Relative Size of the Public Sector}

As regards their effect on resource allocation, the different parts of government revenue are very heterogeneous. There are taxes that are not distorting, but 
essentially corrective. The fuel tax is an example. It serves, in the first place, to fund road infrastructure. To this extent, it can be seen as the price for using a scarce, but expandable resource. Hence, by way of the tax, "the market" can ultimately decide how extensive road infrastructure will become. If correctly calculated, the tax on carbon emissions that is advocated by many economists can also be understood as a corrective "Pigou tax."

The taxes that yield the most revenue are the sales tax in the modern form of the "value-added tax" and the income tax. These taxes have a distorting effect. They amount to taxes on the market-mediated division of labor. Work in which producer and consumer are identical-for instance, domestic work like cooking, cleaning, etc., that is performed by the housewife or househusband-is not subject to sales tax or income tax. The work involved in parents' bringing up children is likewise not subject to these taxes. If someone prefers a more "pleasant" job with a lower wage to a less pleasant, but better paid job, this choice is subsidized by the government, since, as a consequence, the tax base is smaller-assuming that the marginal contribution of the employee to national product is proportionate to the wage. Another way of putting this is that "greed" for a higher standard of living is effectively "punished" by the tax authorities.

In Sect. 3.3 of the chapter on desired wealth, we provided an overview of the different charges and taxes to which German employees are subject. Since the retirement benefits that employees will later receive under the public retirement plan depend on the amount of the contributions that they and their employers have paid into the plan, as a first approximation, these contributions are not to be regarded as taxes, but rather as saving. That said, how good of an approximation this still is would have to be tested in detail in light of the currently used benefits formula, as well as other legislative changes. But something else, in any case, is clear: The employee and employer contributions to public health insurance have the character of a tax and hence a distorting effect.

It would be useful in connection with our research if a documented, modified measure of the relative size of the public sector was available for the OECD countries and for China. This would differ from the traditional measure inasmuch as payments to the government would be excluded, if they function, in effect, like "prices" for an equivalent government service. Examples would be elements of the fuel tax and (in Germany) contributions to the public retirement plan, to the extent that the plan's character as a sort of insurance is largely retained.

\subsubsection{Shiller's "TRILLS" Proposal}

Apart from noting that governments should try to limit distorting taxes, so that their bonds do not bear any default risk, we should also consider whether, in parallel to fixed-rate bonds, there are other forms of public debt that are less exposed to default risk. By definition, firms whose shares are traded on the stock exchange are not only financed with fixed-rate bonds, promissory notes or bank loans. Part of their financing consists of equity, which participates in both corporate risk and corporate 
profits. We understand Robert Shiller's TRILLS proposal as a public version of this private form of equity financing (Shiller and Kamstra 2010).

Shiller has been arguing for this idea for a number of years now. He has also found a number of co-authors who, like himself, have been thinking about the exact form such a security could take. A "TRILL" gives its holder the right to one-trillionth of the nominal national product of the country whose government has issued the security. We can, in principle, imagine that this claim is preserved over time. It is also conceivable, however, that a TRILL lays claim to one-trillionth of the national product in the year of its issue, $95 \%$ of one-trillionth, for example, in the following year, $90.25 \%$ of one-trillionth in the year after that, etc. This type of gradually shrinking claim would have the advantage of allowing a country's fiscal authorities also to reduce the total number of outstanding TRILL claims. Note that if there is this kind of "radioactive" decay, then all outstanding TRILLs are perfect substitutes for one another, much like what we know is the case for substances like, for instance, a particular isotope of uranium. This would also assure that TRILLS have high liquidity.

Shiller sees his TRILLS proposal as an expansion of the choices available to the investor. Using calculations, he argues that thanks to the inclusion of TRILLS, the typical American investor could achieve a far better ratio of average returns to return variance than is currently possible without them. For this reason, he predicts that there would be great demand for TRILLs.

But, in addition, he emphasizes the contribution of TRILLS to a greater stability of public finances. If the actual evolution of nominal national product deviates, either upwards or downwards, from what was expected, then the payouts to TRILL holders would move in the same direction. The behavior of tax income is procyclical. Thus, TRILL payouts rise and fall in parallel to tax revenue.

We now provide a brief formal presentation of the TRILL within the framework of a steady-state analysis. As concerns the present, a TRILL entitles its holder to a dividend worth one-trillionth of the national product. In order to connect this discussion to the formal apparatus used in the other chapters of this book, we will work with a different unit, but retain the designation "TRILL." As concerns the present, one TRILL unit entitles its holder to obtain $w$ units of money, whereby $w$ represents net national product per labor year minus the interest on capital employed. Hence, as shown, for example, in Chap. 2, the formula for $w$ is:

$$
w=y-r v(r ; \theta)
$$

As in Chap. 2 on capital theory, the growth rate of the economy per labor year, $g$, is given. A TRILL "shrinks" at a relative speed of $\delta$. Thus, calculated from today, at time $t$ it has come to be $e^{-\delta t}$ units. Accordingly, at time $t$, the dividend is $\bar{w} e^{(g-\delta)}$ ${ }^{t}$, where $\bar{w}$ is the current value of $w$. If, as before, $r$ is the risk-free interest rate and $\alpha$ is the risk premium, then the present value of all cash flows from a current TRILL is

$$
p=\int_{0}^{\infty} \bar{w} e^{(g-\delta-r-\alpha) t} d t=\frac{\bar{w}}{\delta-g+r+\alpha} .
$$


We can assume that $p$ is the market price of a TRILL.

It is possible to calculate the yield on this security by, for example, imagining an investor who wants to keep the value of the TRILLs in his or her portfolio constant. The TRILLs shrink at the rate $\delta$; on the other hand, the dividend grows at the rate $g$. If $\delta>g$, then the investor has to buy TRILLs, in order to keep the value of the TRILLs in the portfolio constant. If $N$ is the number of TRILLs that the investor owns, then his or her current "cash flow" is

$$
\text { CashFlow }=N \bar{w}-N p(\delta-g)=N p(\delta-g+r+\alpha-\delta+g) .
$$

The return on the investment is thus $r+\alpha$. This is also the return if $g>\delta$ : i.e., if the investor is constantly selling TRILLs, in order to keep his or her TRILL assets constant.

This return is the expected return. The risk premium $\alpha$ makes this clear. Inasmuch as the risk premium is the same as that applied by the capital market in the case of fixed-rate government bonds, both types of investment achieve the same expected return. We will come back to the question of the amount of the risk premium below.

The elasticity of tax revenue as a function of national product is empirically greater than one. This is because the tax system as a whole is progressive. In the case of income tax, marginal tax rates are consistently higher than the average tax rates. Moreover, certain of the government's required expenditures have a countercyclical effect: above all, unemployment and welfare. As concerns the modern period, this is a highly robust fact, and it is a fact that reinforces the impact of the government budget and social security as "automatic stabilizers" over the course of the economic cycle. Accordingly, the government's net borrowing has a countercyclical character.

This countercyclical character of net borrowing is somewhat weakened by TRILLS. The magnitude of this effect is modest, however. If we assume that half of explicit public debt takes the form of TRILLs, then at an explicit debt ratio of $200 \%$ in relation to net national product or to private and public consumption, the value of the stock of TRILLs is precisely equivalent to the annual net national product (or to annual consumption). If we assume a figure of $5 \%$ for $\delta$, a (nominal) growth rate $g$ of $3 \%$, a nominal risk-free interest rate $r$ that is also $3 \%$, and a risk premium of $1 \%$, then the price of a TRILL is normally fifty times greater than the annual payout $w$. Hence, the TRILL payments amount to $2 \%$ or one-fiftieth of net national product (or of private and public consumption).

Now, if the nominal growth of national product is only $1 \%$, rather than the expected $3 \%$, then the saving on TRILL dividend payments for this year is $2 \%$ of $2 \%$ of net national product (or of consumption expenditure): i.e., $0.04 \%$. This is not a major contribution to the stabilization of public finances. This calculation can also be made plausible by way of the following reflection. At a risk-free steady state interest rate equal to the growth rate and a "risk premium" of $1 \%$ per year, citizens' holdings of public debt in TRILL-form worth one annual national product costs the government payment of a $2 \%$ "share" in this national product. 
Given the stabilizing effect of TRILLS that we want to present now, we regard it as highly probable that the risk premium on TRILLs, $\alpha$, will not be greater than $1 \%$ per year.

The real contribution of TRILLs to stabilize the economy does not come from the countercyclical payment of TRILL dividends, but rather from the change that they bring about in citizens' long-term arrangements. The problem of a stable currency plays an important role here. We will come back to this question in Chap. 9 on stable money. There, the focus is on the indispensable contribution that stable money makes to prevent voters from destabilizing the government with their demands. Here, we want to discuss how TRILLs can contribute to increase investment security under conditions of price stability.

Most people think in the long-term: among other reasons, because they can expect to live for a long time still and because they have, or can expect to have, children whose well-being is important to them. On the other hand, they also know that politics is more short-term-oriented due to elections. And it is inevitable that the overall economic situation at any given moment will have a strong influence on people's mood: hence, the danger of an inflationary economic policy. Moreover, institutional safeguards can never fully eliminate this danger.

Now, if it follows from our analysis in this book that a high level of public debt both is and will continue to be a requirement for prosperity, then we have to ask how we can deal with people's fear that the government will unload its "debt burden" via inflation.

One answer that has already been put into practice consists of inflation-linked bonds. If there is a developed market for these bonds, their nominal yield in comparison with conventional government bonds proves to be a good indicator of average expected inflation. But once their dissemination has reached a certain level, there is a catch: Such bonds represent a particularly heavy burden for public finances in critical situations in which, at least temporarily, price increases could represent a correct macropolicy response. One example is when there is a sharp rise in the prices of raw materials or even a cutoff of deliveries of raw materials that have to be imported. In this case, it can make sense for monetary and fiscal policy to allow the consequent increase in the domestic price level to take place, so as to ward off a massive drop in investment and a resulting collapse of economic activity. The possibly critical situation of public finances under these circumstances can be exacerbated by the claims of holders of inflation-linked bonds.

By contrast, as shown above, TRILLs are hardly a fiscal burden in the short term when there is a rise in prices. On the other hand, TRILLs are also themselves precisely a form of protection against inflation. A sustained increase in the nominal growth rate by $1 \%$ point per year may well drive the inflation rate up by around $1 \%$ point as well. At the same time, however, this increase means that the growth rate of the annual TRILL dividends also rises by $1 \%$ point, such that holders of TRILLS are not hurt by the higher rate of inflation.

In this respect, TRILLs are comparable to the "dynamic retirement benefits" that were introduced in Germany in 1958. If dynamic retirement benefits are applied in undistorted fashion, current and future recipients of benefits under the public 
retirement plan are protected against inflation so long as the average wage keeps pace with it.

There is also a second problem with inflation-linked bonds that does not arise with TRILLs. What is known to statisticians as the "index number problem" makes clear that the depreciation of the currency cannot be unambiguously measured in the long run-just as, in the same way, real growth cannot be unambiguously measured in the long run. But this measurement problem does not exist for the TRILLs, since only nominal quantities are involved.

Of course, even with the availability of TRILLs as investment, the individual saver cannot be given a guarantee that his or her invested wealth will yield a real return, as expressed in the prices relevant to this saver, at the current real interest rate. For the latter is calculated on the basis of the average rate of inflation for the country as a whole. But what interests the individual saver are the prices of the goods that he or she wants to consume, and the inflation rate for these goods differs from town to town and from region to region. Nonetheless, the TRILL holder can count on there being a tight correlation between the national rate of inflation and the respective regional rates.

The phenomenon of "loss aversion" is well known in behavioral economics. When we think about decisions relating to the distant future, the pressure "not to make a mistake" (and this is what "loss aversion" is) typically involves comparing oneself to other people. But for this purpose, investing in TRILLs is a good moveat least once TRILLs have become well-established. For the success or failure of such an investment never leaves the investor by him- or herself. All one's friends and neighbors have had the same success or failure. In this respect, TRILLs are the counterpart to ETFs on the stock market-except that the risk connected to TRILLs is far smaller.

Introducing TRILLs as an investment instrument would make an important contribution to reducing citizens' mistrust of the government when it comes to public debt. And reducing this mistrust requires a government that, due to the high level of citizens' desired wealth, cannot avoid high public debt, if it wants to ensure prosperity and full employment. TRILLs are a form of "outwitting" the structural short-term orientation of government policy: the discounting discrepancy we described above. In this respect as well, they appear to us to be a better instrument than inflation-linked bonds.

It would seem advisable for the fiscal authorities to choose a mix of traditional government bonds (plus bank loans), inflation-linked bonds and TRILLs in proportions that minimize the overall risk premium that the government has to pay. This roughly amounts to the three forms of investment generating the same expected return. Thus, it is up to investors, viz. to the capital market, to decide what the correct proportions will be.

But even with the TRILLs as investment instrument, the reflections on the relative size of the public sector that we undertook, using the Laffer curve, in Sect. 6.1.8 remain relevant. 


\subsubsection{TRILLs When the Interest Rate Is a Biased Price Signal}

At the end of Chap. 2 on the natural rate of interest, we discussed the situation when the interest rate is a biased price signal. The focus was on the case in which the intertemporal rate of return on a current marginal foregoing of consumption in the form of additional future consumption is greater than the interest rate $r$. So long as the interest rate on the household side does not exhibit any bias $\left(\beta_{2}=0\right)$, the steady-state optimal interest rate is less than the growth rate. Here, we go through a numerical example in which we suppose that the degree of bias on the production side is $2 \%$ per year: thus, $\beta_{1}=0.02$. But, unlike in Chap. 2 , we assume, anticipating the precautionary principle we discuss in Chap. 13, that this results in a steady-state optimal interest rate of $1 \%$ point below the growth rate. Like in the earlier numerical example, we can, furthermore, assume a growth rate of $3 \%$ per year and a risk premium for public debt, $\alpha$, of $1 \%$ per year. In this case, the capital market return on public debt in the steady-state optimum is equivalent to the growth rate, viz. 3\% per year: viz. $r=2 \%$ per year and $\alpha=1 \%$ per year.

This means that if the public debt ratio is constant over time, an increase in public debt of $3 \%$ per year is exactly enough to cover the interest payments. Hence, there is no need for any budgetary primary surplus.

This numerical example has been chosen in such a way that two complicating effects exactly offset each another: on the one hand, the price signal bias of the interest rate and, on the other, the risk premium. We do this with a clear conscience, because the experience of recent years shows that absolutely secure ten-year bonds that are not, however, inflation-linked-like, for instance, the corresponding German government bonds-have a nominal yield that is predominantly below $1 \%$ per year despite the inflation risk associated with them. In light of a eurozone inflation rate of $1 \%$ per year, this corresponds to a real yield of zero at most. Even if we believe that the officially measured rate of inflation in the eurozone overestimates the "actual" rate of inflation - the problem of the Laspeyre-Index, which, especially in light of the raging success of the products of the digital economy, fails to take adequate account of the hedonic price index, or the "Aghion effect" (Aghion et al. 2019) - the real yield of 10-year bonds is still very low. There is little room here for a risk premium.

In Germany, the popular argument against this finding is that interest rates are so low, because the European Central Bank is artificially suppressing them with its monetary policy. It has been nearly a decade now that this counterargument could be heard. But it is no longer plausible. Have we not known since Wicksell that interest rates that are kept artificially low give rise to an inflationary spiral? But no such inflationary spiral has occurred. The more plausible hypothesis is that the ECB policy is merely following the very low full employment equilibrium interest rates in the eurozone. We are thus on the safe side, if we set the risk premium for TRILLs and also for conventional government bonds at $1 \%$ per year in our calculations. 


\subsubsection{Central Bank Money}

Central bank money is put on the liabilities side of the central bank balance sheet. Since the central bank is publicly owned, one can also, purely formally, record it on the liabilities side of a consolidated government balance sheet. But this is not enough to decide whether it is public debt. There is also no consensus on the matter in monetary theory, as far as we know. These differences of opinion have taken on a certain virulence with regard to the eurozone, since the national central banks have significant TARGET balances and they do not have to be periodically settled. We are not going to get involved in this controversy, but we can refer here to Hellwig (2019). In his article, Martin Hellwig adopts the position that in the current monetary conditions that prevail since the end of the Bretton Woods system, central bank money does not represent public debt, because it is not a liability according to the fair value principle. On the other hand, he finds that recording it as a liability is justified on political grounds, in order to prevent the emergence of hard-to-control "desires" to use the central bank's very considerable equity.

For our purposes, it is helpful to consider central bank money as public debt strictly for presentational reasons. The formal apparatus that we have developed for a steady-state analysis can thus remain as presented in Chap. 2 on capital theory, while also including central bank money. It is not necessary to introduce central bank money separately. As we showed in Chap. 2, the formal presentation set out there assumes, in any case, that economic actors optimize their portfolio with respect to the various investments. To the extent that their investments are negotiable, the subjective marginal rate of substitution between two types of investment is, then, equal to one. From this point of view, the liquidity preference of economic actors is, then, just one of many investment options. The same considerations also apply to banks and to their balances with the central bank: i.e., to central bank money. As long as we stick to a steady-state analysis, we also do not need, in our formal presentation, to distinguish between the different maturities of government bonds.

In a model of macroeconomic dynamics, money and central bank money have, of course, to appear as separate variables. But in this book, we are not developing any new model of macroeconomic dynamics. In our view, however, our ideas about the level and form of public debt are important for an adequate dynamic modeling of how the economy as a whole operates.

\subsection{Determining the Value of Explicit and Implicit Public Debt in the OECD Plus China Region}

\subsubsection{Explicit Public Debt}

When the state goes into debt to its citizens, the latter acquire wealth to the same extent. In order to be able to determine empirically the magnitude of this wealth, or, in other words, of the private sector's claims on the state, we will first discuss 
explicit public debt in the present section. Apart from this explicit debt, citizens also have claims on the state in their capacity as beneficiaries of the various branches of the social security system, which we here understand broadly to include not only the public retirement scheme, but also public health and nursing care insurance. ${ }^{1}$ In the following section, we will then examine this form of implicit public debt. It is, on the one hand, far more difficult to determine, but, on the other, as we will show, also far greater than explicit public debt. Our ambitious objective in this empirical part of this chapter is to estimate the magnitude of both explicit and implicit public debt for the 35 countries of what we have described as the OECD plus China region. For the reasons already explained, we then express both the individual components and the sum of explicit and implicit public debt in units of total annual consumption (the sum of private and public consumption in the current year, which in our case is the reference year 2015).

There are certain relationships between explicit and implicit public debt that have to be kept in mind, in order to proceed correctly when empirically determining their magnitudes. Since the introduction of the 2008 System of National Accounts (SNA), some countries show their pension obligations vis-à-vis government employees in the core tables of their national accounts. To this end, the discounted present value of current and future pension payments (accrued-to-date entitlements) to government employees is calculated according to internationally agreed actuarial methods (IMF 2016). Some countries count the underfunded part of their contributions-based pension scheme for government employees as part of explicit public debt, but others do not. ${ }^{2}$

In this chapter, we assign the pension or retirement benefit entitlements of both public sector and private sector employees to implicit public debt. Hence, we will deal with them in detail further on. In order to avoid double counting when calculating total public debt, however, the data of the countries that count the present value of civil servant pension entitlements as part of their explicit public debt has to be adjusted accordingly (IMF 2018b, p. 10, Footnote 23).

For the purposes of our research, a further adjustment has to be made to the usual public debt figures. In this chapter, we want to determine the private sector's financial claims on the state. We need, therefore, to use net public debt rather than gross public debt. To this end, we take the difference between the state's liabilities vis-à-vis the private sector and publicly owned private sector financial assets. The IMF defines net public debt as "Gross debt minus financial assets corresponding to debt instruments" (IMF 2018b, p. 43). Table 6.1 shows these interrelationships.

The financial assets that have to be taken into account to get from gross to net public debt include monetary gold and special drawing rights, currency and deposits, debt securities, insurance, pension and standardized guarantee schemes, and other

\footnotetext{
${ }^{1}$ When, further on, we discuss the specific American program known as social security, we will mark the difference from this broader concept by always using capitals.

${ }^{2}$ Even in the former countries, however, the claims of private sector employees on the public retirement system are neither shown in the core national accounts nor is their present value counted as part of explicit public debt (IMF 2018b, p. 3). In the next section, we will try to estimate the implicit public debt to which they give rise.
} 
Table 6.1 Determining explicit net public debt

\begin{tabular}{|c|c|c|}
\hline$A$ & $B$ & $C=A-B$ \\
\hline $\begin{array}{l}\text { Gross debt (liabilities in the form of } \\
\text { debt instruments) }\end{array}$ & $\begin{array}{l}\text { Financial assets corresponding to debt } \\
\text { instruments }\end{array}$ & Net debt \\
\hline SDRs & Monetary gold and SDRs & \\
\hline Currency and deposits & Currency and deposits & \\
\hline Debt securities & Debt securities & \\
\hline Loans & Loans & \\
\hline $\begin{array}{l}\text { Insurance, pension, and standardized } \\
\text { guarantee schemes }\end{array}$ & $\begin{array}{l}\text { Insurance, pension, and standardized } \\
\text { guarantee schemes }\end{array}$ & \\
\hline Other accounts payable & Other accounts receivable & \\
\hline Total gross debt & $\begin{array}{l}\text { Total financial assets corresponding } \\
\text { to gross debt }\end{array}$ & $\begin{array}{l}\text { Total net } \\
\text { debt }\end{array}$ \\
\hline
\end{tabular}

Source IMF (2013, p. 5)

accounts receivable. Table 6.2 contains the net public debt ratios for 35 countries in the OECD plus China region; for informational purposes, data on gross public debt ratios is also provided. All the data on explicit and implicit public debt in this chapter refers to 2015. As the table shows, public debt decreases considerably, when the financial assets of the public sector are taken into account. On average, the difference between the gross public debt ratio and the net public ratio amounts to no less than $20 \%$ points for the OECD countries (not including Estonia, Chile, Luxembourg and Norway). The difference between the gross and net public debt ratio is particularly great for Japan. In 2015, Japanese public debt amounted to $231 \%$ of gross domestic product (GDP). The net public debt ratio is less, however, since a significant part of the debt securities issued by the government to finance public expenditure during the last decade are held by the Japanese central bank, which is likewise part of the public sector. Another part of the difference between gross and net debt is a result of the fact that the Japanese government has made considerable financial investments via public pension funds. As consequence, far less that $231 \%$ of gross domestic product in 2015 can be attributed to Japanese public debt: namely, only $147 \%$. We may only use this figure in calculating the claims of private persons on the state in Japan. Much the same applies for the USA. Like in Japan, the unconventional monetary and fiscal measures that were used to combat the effects of the great recession in the USA also led to massive purchases of government securities by the Federal Reserve. Due to the fact that the Federal Reserve and certain other public institutions have extensive holdings in government bonds, and because of the public pension fund for government employees, explicit net public debt in 2015 only came to about $80 \%$ of GDP. This is considerably less than the explicit gross public debt, which amounted to nearly $105 \%$ of GDP in the USA in 2015 . Here too, only the explicit net public debt can be assigned to the private sector as assets.

In some countries, the financial assets even exceed gross debt, such that net wealth is positive. The remainder is particularly great in the case of Norway, which has invested a large part of its oil revenue in a sovereign wealth fund. As shown in Table 6.2 (column B), the net value of Norway's public sector financial assets 


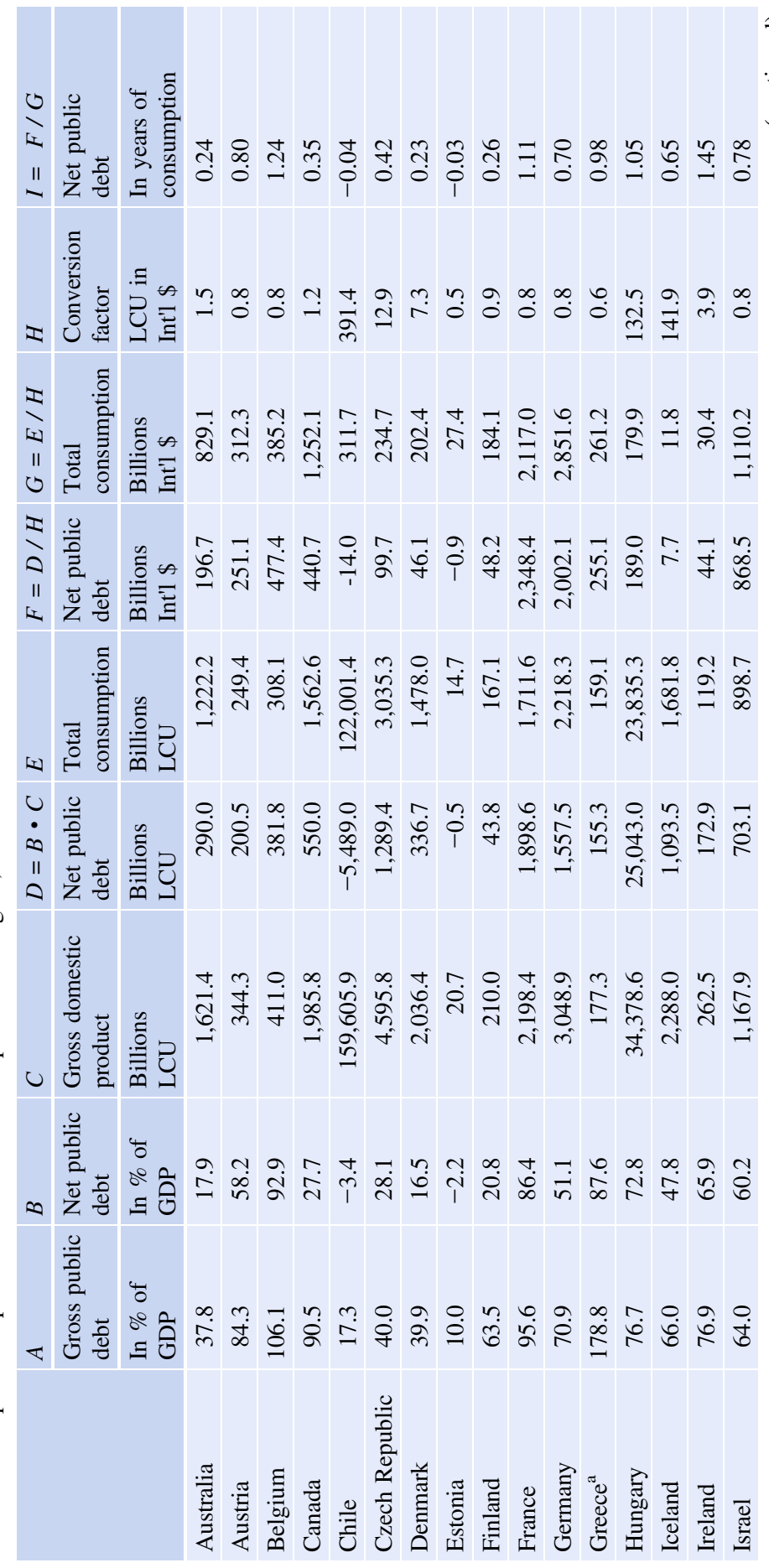




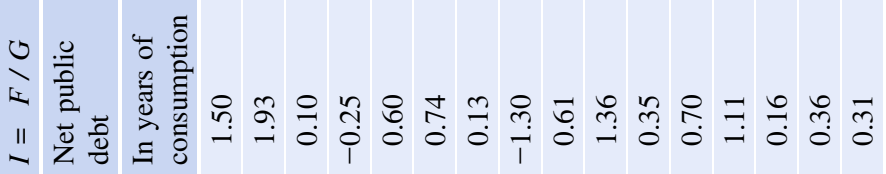

ヌ

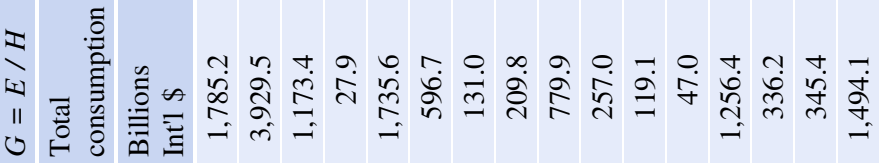

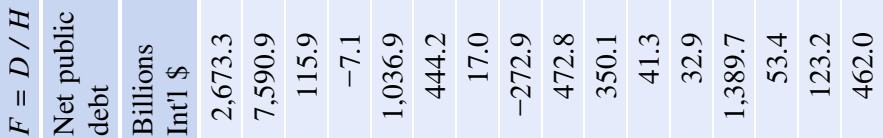



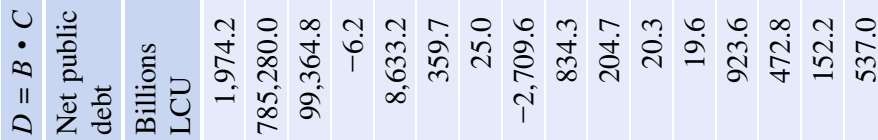

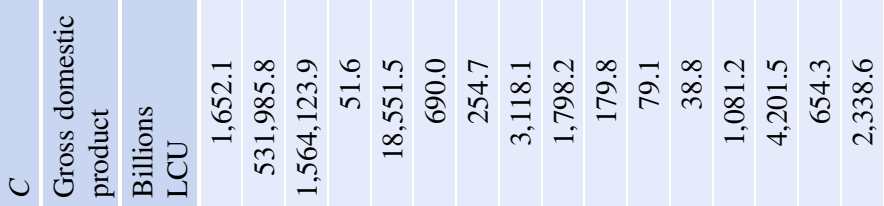

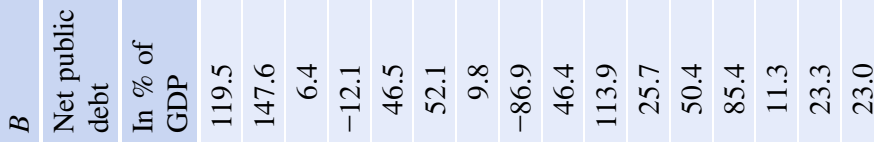

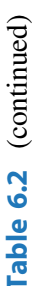



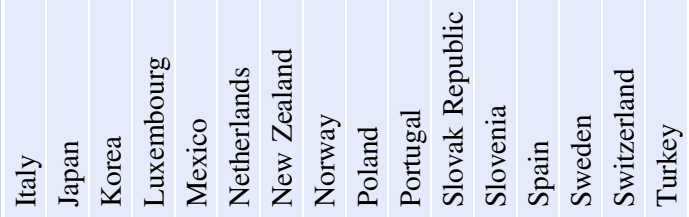




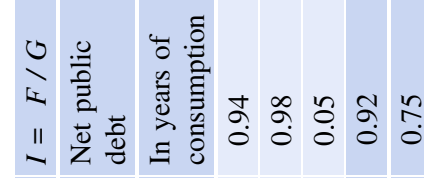

エ

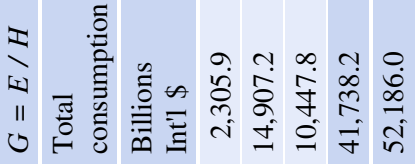

$\pm$

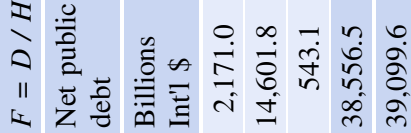

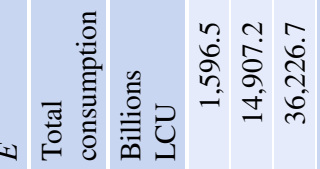

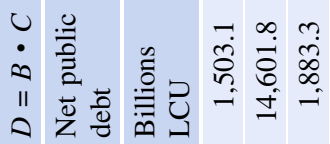

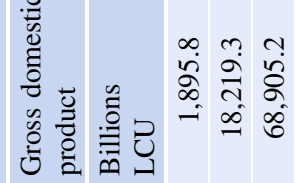

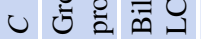

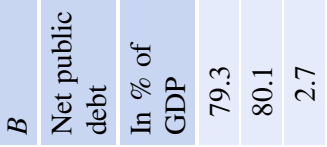

气

芒

ฮิ

离 
amounts to almost $87 \%$ of GDP. But the net wealth of the public sector is also positive in Chile, Estonia and Luxembourg. These countries are, however, exceptions in the OECD. As a rule, the OECD countries have positive net public debt. Among the OECD countries with positive net public debt, this debt was, on average, around $55 \%$ of GDP in 2015. With a net debt ratio of $51 \%$ of GDP, Germany was somewhat below the average for the OECD countries. China's net debt ratio is extremely small: In 2015, it came to only $2.7 \%$ of GDP. According to the IMF, China's gross public debt is $41 \% .^{3}$

The IMF shows net public debt for the OECD countries and for China as a percentage of GDP (cf. Table 6.2, column B). Multiplying this figure by the 2015 value of GDP for each country (column C), we obtain, in column D, the explicit net public debt in the respective local currency. Our objective is to determine explicit public debt for the whole OECD plus China region. To this end, the figures in the respective local currency are converted into international dollars (purchasing power parities). Column F shows explicit net public debt, which we will simply call explicit public debt from now on, in international dollars. Since we ultimately want to express the wealth of private households in units of total annual consumption, we also convert the country-specific consumption figures in the respective local currencies (column E) into international dollars. At the bottom of column F, we find, on the one hand, total explicit public debt for all the OECD countries, not including China: In 2015, this total came to 38.6 trillion international dollars. On the other hand, total explicit public debt for the OECD countries plus China is also shown. In 2015, the latter came to 39.1 trillion international dollars. In 2015, total consumption amounted to 41.7 trillion international dollars in all the OECD countries combined. If we add China, we arrive at a figure of 52.2 trillion international dollars. Finally, we relate the explicit public debt of the OECD countries or, respectively, of the OECD plus China region to annual consumption. The end result is that explicit net public debt in the OECD countries amounted to $92 \%$ of their annual consumption in 2015. China's exceptionally low public debt, as compared to the average for the OECD countries, significantly reduces the overall figure due to the great weight that China has in the OECD plus China group. Thus, explicit net public debt in the OECD plus China region came to around three-quarters of annual consumption in 2015.

\footnotetext{
${ }^{3}$ On China, the IMF (2018b, p. 23) writes tersely: "Compiling China's general government balance sheet is a challenge." In its Global Debt Database, the IMF does not itself provide a figure for China's net public debt. However, in the focus box "China - Revisiting the General Government's Balance Sheet" (ibid.), the IMF undertakes some estimates of the liabilities and financial assets of the Chinese state. We have derived our figure of $2.7 \%$ for Chinese net public ratio from these estimates.
} 


\subsubsection{Implicit Public Debt}

\subsubsection{Public Retirement Schemes}

Having determined the level of the explicit public debt of the OECD plus China region in years of total annual consumption in the previous section, we will now estimate the level of implicit public debt. What appears as debt from the point of view of the public sector is wealth for the private sector. In what follows, we will examine the claims of households on the state that have come into being as a result of contributions paid into pay-as-you-go social security systems. The present value of the future cash flows to which households are entitled, given the rules applicable at a given date and the contributions that have been paid until then, represents an extremely important component of their wealth. For the state, the present value of these future cash flows from the different branches of the social security system represents an implicit liability. We regard a pay-as-you-go social security schemethe mechanism of which we have examined in detail in Sects. 6.1.3 and 6.1.4-as a kind of funded scheme without a reserve fund. The missing reserve fund for the different branches of social security represents the implicit public debt.

Among these different forms, the public retirement scheme makes by far the largest contribution to this implicit public debt. We need to add the implicit public debt represented by civil service pensions, which are directly funded from tax revenue. ${ }^{4}$ The other branches of social security also add to implicit public debt. This is, above all, the case for public health insurance and nursing care insurance, with which we will deal in a later section.

The objective of the present section is to estimate the public debt that derives from the public retirement scheme. More specifically, what we want to do is to determine the present value of the future claims of beneficiaries of the public retirement scheme and the future pension claims of civil servants and to express this value in years of total consumption. These claims are also known as accrued-to-date pension entitlements in the international statistics, with "pensions" here covering both of the aforementioned categories. The basic data on which our calculations are based comes from a variety of sources. In what follows, we describe the data sources and the procedure used in our calculations for the European countries, for the USA and for the other countries of the OECD plus China region.

\section{Europe}

One of the innovations connected to the introduction of the 2008 System of National Accounts (2008 SNA) and the 2010 European System of Accounts (ESA 2010) consists of the fact that participating countries have set themselves the objective of regularly reporting retirement benefit and pension entitlements-here

\footnotetext{
${ }^{4}$ In Germany, the federal government and some of the individual states or Bundesländer have begun to build up reserves for the future financing of civil service pensions. These reserves have to be subtracted from implicit public debt. Up to now, however, they are nowhere near adequate to cover the future pension claims of retired civil servants. In the USA, only about half of the pension obligations owed to public sector employees are currently covered. The section below on the USA provides more details on this.
} 
designated uniformly as "pension entitlements" - arising from unfunded systems (European Commission et al. 2009; Eurostat 2013 ${ }^{5}$ ). Every three years, European Union member states are required to calculate "accrued-to-date pension entitlements in social insurance" and to report them to Eurostat, the statistical office of the European Union. Since 2018, data is available on the level of retirement benefit and pension entitlements for the year 2015 for 26 European Union countries, as well the EFTA countries Switzerland, Norway and Iceland. ${ }^{6} 22$ of these 29 countries belong to the OECD plus China region that we are investigating.

Retirement entitlements are here understood as the present value of future retirement benefit and pension payments (projected benefit obligation) based on already acquired claims as of the balance sheet date. The method thus follows the accrued-to-date-liabilities (ADL) principle: The only claims that are taken into account are those that have been acquired in the past by current retirees or workers paying into the scheme. Claims acquired after the balance sheet date are left out. We thus establish the present value of the entitlements that exist if the retirement scheme were to be wound up on the balance sheet date (Holzmann et al. 2004; Freudenberg 2017, p. 328). Figure 6.2 shows the different approaches used in calculating the present value of benefit entitlements in a retirement scheme.

The ADL method is a method that only takes into account already acquired entitlements of current members of the retirement scheme. Future payments into the system (both retirement scheme contributions and other contributions), i.e., payments made after the balance sheet date, are not taken into account by the ADL method (cf. Box 1 in Fig. 6.2). If, in the context of a closed system, payments that current workers will make in the future are also taken into account, then we speak of a CWL (projected current workers' and retirees' liabilities) method (cf. Box 2 in Fig. 6.2). We say the system is "closed," because both methods only calculate the present values of the entitlements of workers or retirees who are already part of the system. In calculating the projected benefit obligation, open systems also take into account the present value of future benefit payments to future members. This is known as the open-system liabilities or OSL method (cf. Box 3 in Fig. 6.2). ${ }^{7}$ Like the statistical offices, we base our reflections and calculations in what follows on the ADL method.

What interests us here are social security retirement schemes and pension schemes providing benefits to civil servants and other government employees. According to Germany's Federal Statistical Office, the present value of households' social security retirement entitlements in Germany came to 6843.9 billion euros at the end of 2015 (Haug 2018). The Statistical Office calculated a present value at the end of 2015 of 1235.2 billion euros for civil service pensions to be paid by the

\footnotetext{
${ }^{5} \mathrm{Cf}$., in particular, the section titled "Supplementary Table for Accrued-to-Date Pension Entitlements in Social Insurance" in Chap. 17 (Eurostat 2013, pp. 379).

${ }^{6}$ Due to the fact that 2015 is the first year for which data on pension entitlements was published by Eurostat and the OECD, we have used this year as the reference year for the empirical estimates of all wealth components in this book.

${ }^{7}$ Holzmann (1998); Braakmann et al. (2007, pp. 1169); Freudenberg (2017, p. 329); van der Ven and Fano (2017, pp. 319).
} 

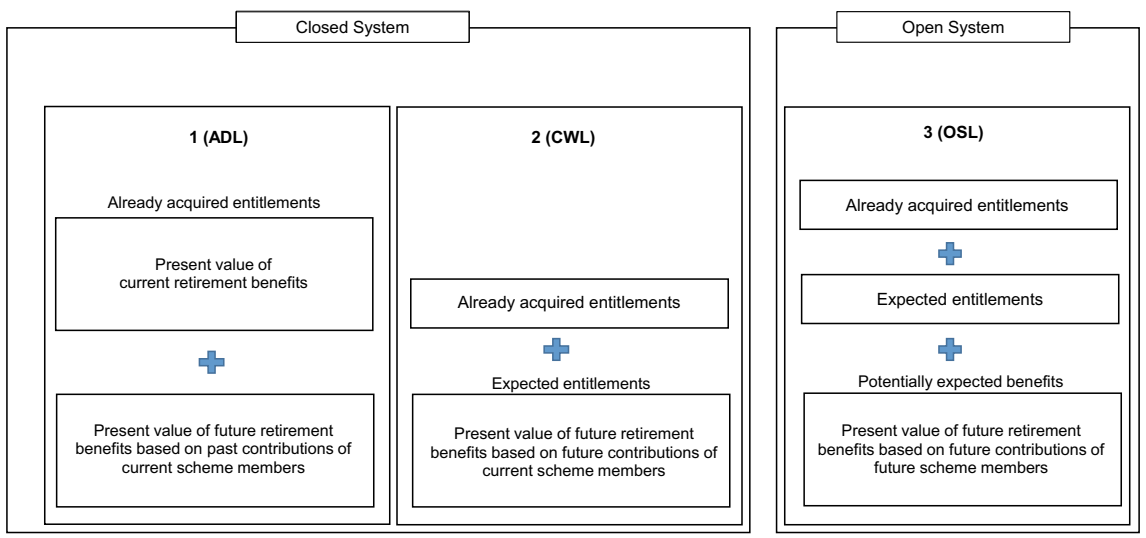

Fig. 6.2 Methods for determining projected benefit obligations. Sources Modified diagram following Braakmann et al. (2007, p. 1169), Freudenberg (2017), Holzmann (1998)

federal government, the states (the Bundesländer) and municipalities (ibid., p. 87, Table 1$)^{8}$

When determining the present value of future cash flows, the discount rate is of decisive importance. The usual assumption is that a positive real interest rate should be used to discount to a present value. The results of the calculations of the European statistical offices provided below are derived from a base case scenario that assumes a nominal discount rate of 5\%. The discount rate is the same for all Eurostat countries and is applied for "a very long period of time" (ibid., p. 89). The discount rate is set by an EU working group, which makes a series of assumptions about the future development of significant economic parameters like demographic change, productivity, wage growth and so on (ibid., p. 89). ${ }^{9}$ Since the calculated present value is highly dependent on the discount rate applied, each of the European statistical offices responsible for determining the retirement benefit and pension entitlements for their respective countries is required by the ESA 2010 to perform so-called sensitivity analyses using other discount rates. The base case scenario, from which the abovementioned figures for Germany's retirement claims are derived, assumes a rate of inflation of $2 \%$ per year, such that the base case

\footnotetext{
${ }^{8}$ Haug (2018, p. 88) notes that "accrued-to-date social security retirement entitlements... are not to be interpreted as public debt." He argues, on the one hand, that future contributions are not set off against them and, on the other, that the full amount of the entitlements "is not legally guaranteed": "Thus, legislative reforms can affect the scope of social security benefits." These are legitimate points. Nonetheless, the approach that we have adopted in this book grasps such entitlements as implicit public debt for reasons that we have laid out in detail in Sects. 6.1.1-6.1.5. A further important reason is that Germany's constitutional court, the Bundesverfassungsgericht, has accorded such entitlements the protection given to property under Article 14 of Germany's constitution.

${ }^{9} \mathrm{~A}$ number of other assumptions are needed, some of which have a major impact on the amount of the present value. These include assumptions on mortality, the rate of inflation, wage growth, etc. (Braakmann et al. 2007).
} 
scenario's real discount rate comes to $3 \%$ per year. In two alternative scenarios, present values of retirement entitlements are calculated using a discount rate $1 \%$ point over and $1 \%$ point under the discount rate in the base case scenario (i.e., at nominal rates of 4 and $6 \%$ per year, respectively). Since a rate of inflation of $2 \%$ is assumed here too, the real discount rates in the two alternative scenarios come to $2 \%$ and $4 \%$ per year, respectively.

Table 6.3 shows the level of retirement benefit and pension entitlements deriving from social security retirement schemes and pension schemes for public sector employees (mainly civil service pensions) for each of the European countries. For some of the countries, however, no data is available on the level of pension obligations owed to public sector employees. Hence, the total column on the right underestimates the amount of accrued benefit claims in the European countries. The economic importance of the entitlements, and hence the implicit public debt deriving from retirement benefit and pension claims, varies significantly among the countries we are considering here. But this can only be made clear once the amount of the entitlements has been converted into a common currency and placed in relation to each country's annual consumption. This will be done further on.

\section{USA}

To estimate the implicit public debt in the US, we need to distinguish between the pension entitlements of public sector employees and the retirement entitlements of private sector employees who receive social security benefits in old age. For both calculations, we can draw on data from official statistics.

\section{Pension Entitlements of Public Sector Employees in the USA}

Data on the present value of pension entitlements of federal, state and local government employees is available for the USA. Since the transition to the 2008 System of National Accounts in the USA, these pension entitlements of public sector employees are shown in the National Income and Product Accounts (NIPA) (Reinsdorf et al. 2014; Stefanescu und Vidangos 2014). They are accordingly recorded as assets in the household sector. In order to determine what part of this must be regarded as implicit public debt, a few preliminary considerations are necessary.

Two different types of schemes can be distinguished in the US pension system. On the one hand, there are defined contribution plans, in which plan members' agreed contributions are invested in one or more selected funds, whereas the resulting income and hence the amount of the future pension payments is not fixed. The capital market risk is principally borne by the plan members. Besides these defined contribution plans, there are also defined benefit plans. In the case of the latter, the amount of future payments is guaranteed by the plan or by the employer, which thus bears the capital market risk. In the USA, both private and public retirement plans are either completely or at least partially funded. If a defined benefit plan is only partially covered by financial assets (if there are, in other words, 
Table 6.3 Accrued-to-date social security retirement benefit and civil service pension entitlements in Selected European Countries, 2015

\begin{tabular}{|c|c|c|c|}
\hline \multirow[t]{2}{*}{ Country } & $\begin{array}{l}\text { Social security } \\
\text { retirement } \\
\text { schemes }\end{array}$ & $\begin{array}{l}\text { Defined benefit pension schemes } \\
\text { for general government } \\
\text { employees }^{\mathrm{b}}\end{array}$ & $\begin{array}{l}\text { Total retirement } \\
\text { benefit and pension } \\
\text { claims }\end{array}$ \\
\hline & Billions LCU & Billions LCU & Billions LCU \\
\hline Belgium & 941.46 & 181.93 & $1,123.39$ \\
\hline Bulgaria $^{a}$ & 140.55 & n.a & 140.55 \\
\hline Czechia & $10,549.00$ & n.a & $10,549.00$ \\
\hline Denmark & 84.10 & 567.95 & 652.05 \\
\hline Germany & $6,843.92$ & $1,235.22$ & $8,079.14$ \\
\hline Estonia & 50.84 & 1.54 & 52.38 \\
\hline Ireland & 231.00 & 114.50 & 345.50 \\
\hline Spain & $2,792.23$ & 310.09 & $3,102.32$ \\
\hline France & $6,948.00$ & $1,160.00$ & $8,108.00$ \\
\hline Croatia $^{a}$ & 807.24 & n.a & 807.24 \\
\hline Italy & $5,631.63$ & n.a & $5,631.63$ \\
\hline Cyprus $^{\mathrm{a}}$ & 32.71 & 7.33 & 40.04 \\
\hline Latvia $^{a}$ & 41.77 & 1.63 & 43.40 \\
\hline Lithuania $^{\mathrm{a}}$ & 99.59 & 1.62 & 101.21 \\
\hline Hungary & $82,349.20$ & n.a & $82,349.20$ \\
\hline Malta $^{\mathrm{a}}$ & 21.93 & 2.91 & 24.84 \\
\hline Netherlands & $1,153.29$ & 11.01 & $1,164.30$ \\
\hline Austria & $1,044.41$ & 211.12 & $1,255.53$ \\
\hline Poland & $4,381.93$ & 426.09 & $4,808.03$ \\
\hline Portugal & 370.84 & 190.91 & 561.75 \\
\hline Romania $^{a}$ & $1,295.48$ & n.a & $1,295.48$ \\
\hline Slovenia & 121.71 & n.a & 121.71 \\
\hline Slovakia & 223.93 & 24.12 & 248.05 \\
\hline Finland & 631.53 & n.a & 631.53 \\
\hline Sweden & $8,490.59$ & 289.22 & $8,779.81$ \\
\hline UK & $4,027.15$ & 916.80 & $4,943.95$ \\
\hline Iceland & $1,605.90$ & n.a & $1,605.90$ \\
\hline Norway & $7,480.00$ & 690.60 & $8,170.60$ \\
\hline Switzerland & $1,350.40$ & n.a & $1,350.40$ \\
\hline
\end{tabular}

Source Eurostat (2020), Authors' own calculations

Notes Retirement benefit and pension claims that are not included in the core national income accounts. Closing balance sheets

${ }^{a}$ Not part of the OECD plus China region (see Chap. 3.11)

${ }^{\mathrm{b}}$ General government employees classified in general government

$L C U$ : Local currency unit

n.a: not available 
unfunded liabilities), then the invested capital is not sufficient to cover all future benefit payment commitments. ${ }^{10}$

The contributions paid into pension schemes by public sector employees are also invested to a large extent on the capital market. In the case of civil servants enrolled in defined benefit schemes, any emerging gap between the capital income from invested contributions and promised pensions has to be covered by the government (Novy-Marx and Rauh 2011). For us, the amount of the unfunded liabilities vis-àvis public sector employees represents the part of implicit public debt in the USA that derives from the civil service pension scheme. For the public sector employees themselves, on the other hand, the unfunded liabilities represent assets that they are guaranteed by the government. ${ }^{11}$

Since the 2007-08 financial crisis, the share of unfunded liabilities in the US retirement system has increased significantly. Around twenty years ago, state and local government pensions were still fully funded. At the time, assets even exceeded liabilities by $7.8 \%$ (Lenze 2013, p. 2). By contrast, in 2019, state and local government pension funds had assets that still covered only $54 \%$ of the overall liabilities under the defined benefit plans (cf. Fig. 6.3). The financial crisis made itself felt on the assets side especially, as Fig. 6.3 clearly shows in comparing the value of financial assets before and after 2008.

According to the calculations of the Federal Reserve, the liabilities of state and local government defined benefit pension plans, expressed as pension entitlements, amounted to 7754.4 billion dollars at the end of 2015 (Board of Governors of the Federal Reserve System 2020b). The assets came to 3679 dollars. The difference between the liabilities and the assets of defined benefit pension plans are unfunded liabilities. They represent claims on the state or "claims of pension fund on sponsor" (ibid., table L.119 and table L.120, line 17; Munnell et al. 2014). At the end of 2015, these came to 4075.3 billion dollars. To this, we need to add the claims from the corresponding pension plans for federal government employees. In 2015 , the present value of unfunded pension obligations owed to federal government employees in the USA came to 1732.3 billion dollars. The total present value of public sector employee pension entitlements in the USA thus amounted to 5807.6 billion dollars in 2015 .

\footnotetext{
${ }^{10}$ The situation is different for people who receive their retirement benefits from private retirement plans and/or from the social security program. Private pensions represent claims and liabilities within the private sector. They thus play no role in the context of interest to us, in which what is at issue are the claims of the private sector on the state.

${ }^{11}$ According to the Center for Retirement Research (CRR), a large number of American public sector pension funds are significantly underfunded. For example, Kentucky's scheme for so-called non-hazardous workers is now only $12.8 \%$ funded. This is due, among other things, to the fact that the fund has not recovered the losses suffered in the dotcom bust. The deficit of all public sector pension funds monitored by the CRR was more than 1.6 trillion US dollars in 2018 (The Economist 2019, p. 65).
} 


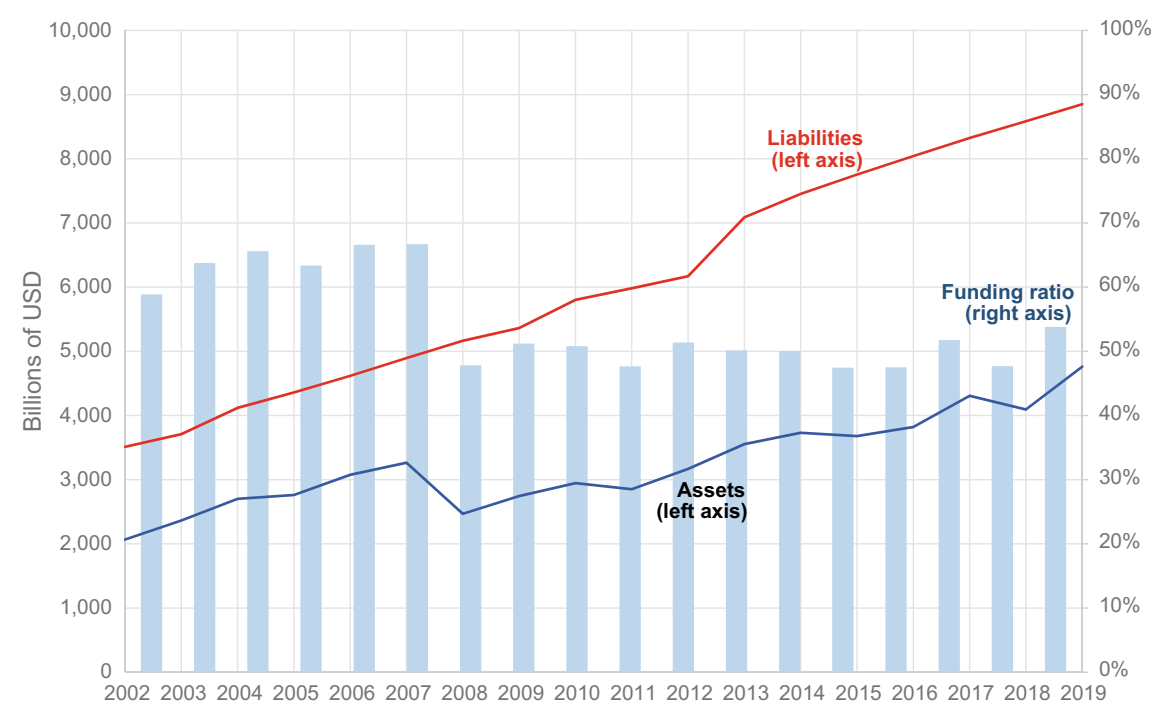

Fig. 6.3 Liabilities, Assets and Funding Ratio for Public Sector Employee Pensions in the USA, 2002-2019. Source Board of Governors of the Federal Reserve System (2020a). Notes Liabilities and assets of defined benefit pension plans are for state and local government employees only. Funding ratio: assets as percent of liabilities

\section{The US Social Security Scheme}

The US social security program is responsible for the retirement benefits of private sector employees. Like in many other OECD countries, it is largely conceived as a pay-as-you-go system.

Social security in the USA consists of the Old-Age and Survivors Insurance and the Disability Insurance programs (together OASDI ${ }^{12}$ ) (Board of Trustees OASDI 2020). In the following, we summarize the expenditure for both programs and refer to it as social security expenditure for the sake of simplicity. ${ }^{13}$ In 2015 , our reference year for calculating explicit and implicit public debt, the USA spent around 910 billion dollars on social security (Board of Trustees OASDI 2016); this is equivalent to around 5\% of the US GDP in 2015.

Since part of employee contributions are paid into a corresponding Trust Fund, social security is a so-called partially funded retirement scheme. The deposits in the Trust Fund have been declining in recent years, however, such that the fund is

\footnotetext{
12،"The OASDI program consists of two parts. Retired workers, their families and survivors of deceased workers receive monthly benefits under the Old-Age and Survivors Insurance (OASI) program. Disabled workers and their families receive monthly benefits under the Disability Insurance (DI) program” (Board of Trustees OASDI 2020, p. 1).

${ }^{13}$ Among other things, social security is responsible for the provision of "monthly benefits designed to replace, in part, the loss of income due to retirement, disability, or death. Entitlement to benefits and benefit levels are related to earnings in covered work and defined by law. Coverage is nearly universal; about $96 \%$ of U.S. jobs are covered" (OECD 2020bb, p. 10).
} 
expected to be depleted, on the Trustees' intermediate assumptions, by the mid-2030s (Board of Trustees OASDI 2020, p. 3).

The US has recently started to provide data on social security retirement schemes to the OECD. From this data, we can obtain information on accrued-to-date entitlements. The methodology used to calculate US retirement entitlements differs in some respects from that used by Eurostat. This relates, in particular, to some key actuarial assumptions (Board of Trustees OASDI 2020; OECD 2020a, b). ${ }^{14}$ However, we follow the OECD's approach of combining the data of the Eurostat countries and those of the US in a supplementary table on what are here called, in keeping with the ESA/Eurostat terminology, "social insurance pension schemes." We take the data for accrued-to-date social security retirement benefit entitlements from this table.

The supplementary table was introduced as part of the 2008 SNA. It is intended "to provide a comprehensive overview of liabilities of all social insurance pension schemes in an economy..." (OECD 2020a, p. 1). One of its essential purposes is to create "...a framework for compiling and presenting comparable balance sheets and transactions and other flow data of all types of pension entitlements. The table also covers stock and flow data not fully recorded in the core national accounts for specific pension schemes such as government-unfunded defined benefit schemes with government as the pension manager, and social security pension schemes" (Eurostat 2013, p. 379).

The USA calculates the value of government-unfunded defined benefit pension schemes and social security retirement (here also called "pension") schemes as follows: "The pension entitlements for the Federal OASDI fund are calculated as the sum of the value of assets in the fund and the maximum transition cost based on a 100 year projection period. The maximum transition cost is equivalent to the unfunded accrued obligation of a plan designed to be fully advanced-funded at the time of plan termination" (OECD 2020b, p. 10).

Based on this methodology, the relevant agencies in the USA calculated the value of accrued-to-date retirement benefit entitlements in social security and reported it to the OECD. The data that the USA submitted to the OECD indicates that the current value at the end of 2015 of accrued-to-date social security retirement benefit entitlements not fully recorded in the core national accounts is $34,812.5$ billion US dollars. We will use this figure in our further calculations.

In our opinion, the unfunded portion of the pension liabilities of public sector employees in the USA would have to be added here. As shown above, their present value was 5835.5 billion US dollars in 2015. However, the USA did not submit data to the OECD for the category "Defined benefit schemes for general government employees - administered by general government - not included in the core SNA accounts." Therefore, we only use the official data published by the OECD in its table 2900 on "Social Insurance Pension Schemes" (OECD 2020a).

\footnotetext{
${ }^{14}$ In the USA, different discount rates are applied for different time periods (OECD 2020b, p. 10). In contrast, Eurostat uses a uniform discount rate, but also performs a so-called sensitivity analysis (cf. the above section on Europe; OECD 2019, p. 8; Mink and Rodríguez-Vives 2010, p. 90).
} 
The value for retirement benefit entitlements of US social security schemes of $34,812.5$ billion US dollars is equivalent to $234 \%$ of 2015 US total consumption. According to our approach, this amount would correspond to the implicit public debt from the public retirement scheme in the USA at a positive real interest rate of about $3 \%$.

\section{The Other Countries in the OECD plus China Region}

In addition to the USA and the European OECD countries listed above, Israel and Mexico have also recently submitted related data on "accrued-to-date pension entitlements in social insurance" to the OECD. Other OECD countries, however, have not provided data despite a basic agreement reached within this institution. These countries include Australia, Canada, Chile, Greece, Japan, Luxembourg, New Zealand, South Korea and Turkey. ${ }^{15}$ In addition, there is China, which is not a member of the OECD, but which is part of the OECD plus China region we are looking at. We are thus faced with the task of undertaking a rough estimate to determine the present values of social security retirement benefit entitlements for nine countries (eight OECD countries plus China).

To this end, we draw on a study of entitlements in international retirement systems that were carried out by Müller et al. (2009). It found that one of the most important determinants influencing the level of country-specific entitlements deriving from the retirement system is the country's current level of retirement benefit expenditures. According to the study, currently paid benefits are an expression of the generosity of each retirement system and the age structure of the population (Freudenberg 2017, p. 332; Kaier and Müller 2015). If retirementrelated entitlements are calculated according to the accrued-to-date-liabilities principle, as is done by Eurostat and in the USA, then current retirement benefit expenditures represent a sound basis for calculation. This is because around half of all benefit claims are attributable to persons who are already retired.

The entitlements calculated by Müller et al. (2009) using the accrued-todate-liabilities method exhibit a high correlation to benefit expenditures in the reference year. The authors determined that the present value of future benefit flows is equivalent to approximately 28-times the benefit expenditures (in both cases, as a percentage of GDP) in the reference year. ${ }^{16}$ Thus, for example, in 2006, retirement benefit expenditures in Germany amounted to approximately $12 \%$ of GDP and entitlements came to around $340 \%$ of GDP. A country like Lithuania, on the other hand, only spent $6.5 \%$ of its GDP on retirement benefits in 2006, whereas retirement-related entitlements amounted to around $180 \%$ of Lithuania's GDP in the same year (Freudenberg 2017, p. 332).

\footnotetext{
${ }^{15}$ Greece and Luxembourg do not transmit their data to Eurostat or the OECD, as they are supposed to remain confidential. New Zealand indicated that there are no social insurance pension schemes in the country (OECD 2019, p. 9).

${ }^{16}$ Just like in the Eurostat base case scenario, a real discount rate of $3 \%$ is used here. Since the ADL approach is applied in the form of the Projected Benefit Obligation (PBO) method, in which expected future wage increases are included in the calculation of entitlements, the figures determined here are in principle compatible with the Eurostat calculations.
} 
The correlation between retirement benefit expenditures and present value of retirement-related entitlements is given by the equation $y=28.052 x+0.0333$ (ibid., p. 332). ${ }^{17}$ Only Finland, Latvia and the Netherlands deviated somewhat more clearly from this relationship in the study. But the deviations in the case of these countries were distributed both upwards and downwards. Since in what follows we will apply this method of estimation to a group of countries, we assume that, on average, we arrive at a reasonably acceptable result by using it. We are aware, of course, that this is only a very rough method for estimating the present value of entitlements in countries for which we do not have any other data. It seems to us, nonetheless, to be an acceptable one for our purposes.

The retirement benefit expenditures of these countries vary considerably (OECD 2017a). As a percentage of GDP, their average for the period 2013-2015 ranged from 4\% in Australia to over 10\% in Japan. Whereas the unweighted average for all OECD countries came to about $9 \%$ in this period, the unweighted average for the nine countries we are considering here was only $7 \%$. Five of the countries were under the OECD average. Greece represents an outlier at around $16 \%$. This can be attributed to the contraction of Greek GDP in the period in question. As described above, the present value of retirement benefit entitlements in relation to GDP was determined by multiplying benefit expenditures as a percentage of GDP by a fixed factor taken from the study by Müller et al. (2009). The present values of retirement benefit entitlements for the individual countries are given in the respective local currencies (LCU) in column A of Table 6.4.

\section{Aggregating the Retirement Benefit Results Using a Positive Discount Rate}

The countries for which data on retirement-related implicit public debt could be obtained from the described official statistics include 29 European countries (of which 22 belong to the OECD plus China region that we have defined) and three non-European OECD countries (the USA, Mexico, Israel). For the remaining eight OECD countries plus China, we estimated retirement benefit entitlements using a simple method taken from the relevant literature. We are conscious of the fact that this procedure only allows for a rough estimate. We assume that the existing gaps in the data will be closed shortly, since at least the eight still missing OECD countries are likewise constructing their national accounts on the basis of the 2008 SNA and the latter stipulates that countries should regularly report figures on the stocks and flows of their retirement benefit and pension entitlements.

We now want to determine the implicit public debt arising from retirement systems for the entire OECD plus China region on the assumption of a real interest rate of three percent (USA: about 2.5\%) and as measured in years of total consumption. We start from the individual country figures for implicit public debt that have been established as previously described. Table 6.4 presents the intermediate steps and the results of the calculations. Column A shows the implicit public debt

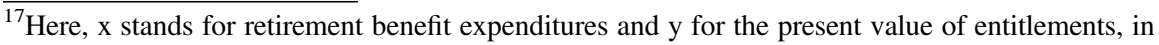
each case as a percentage of GDP.
} 


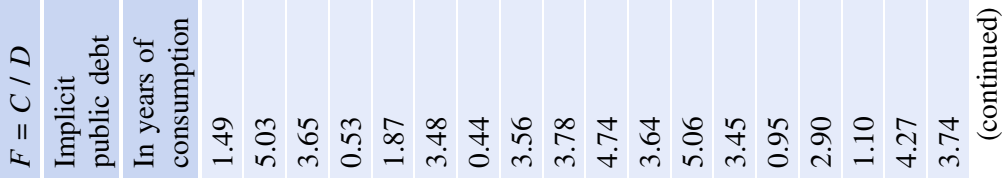

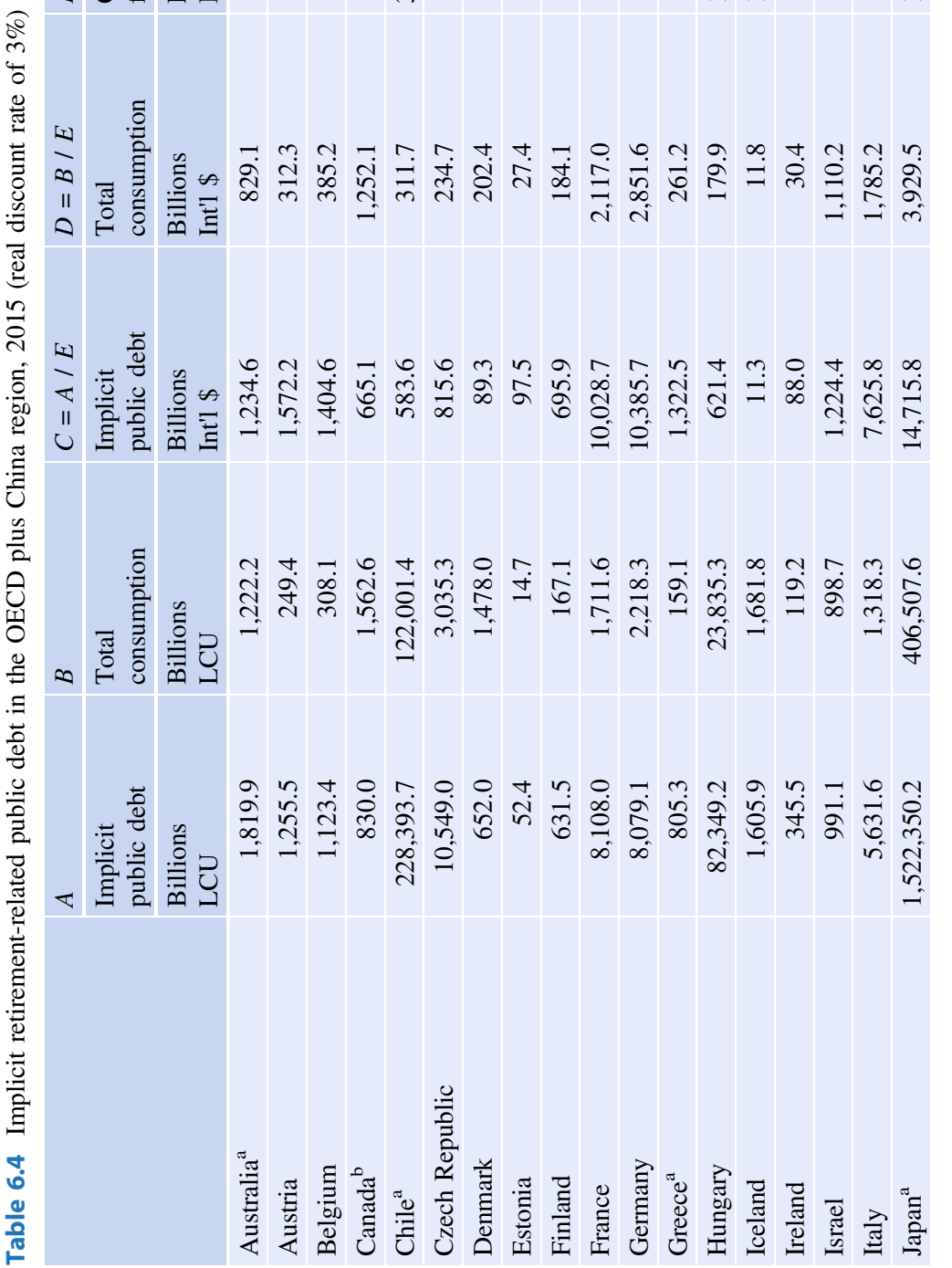




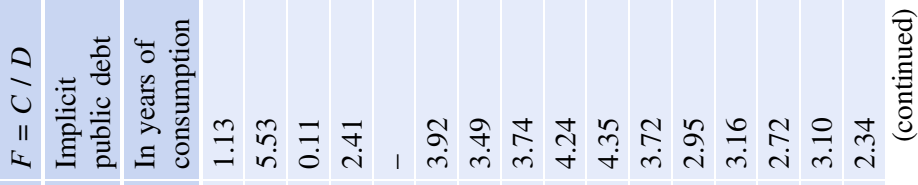

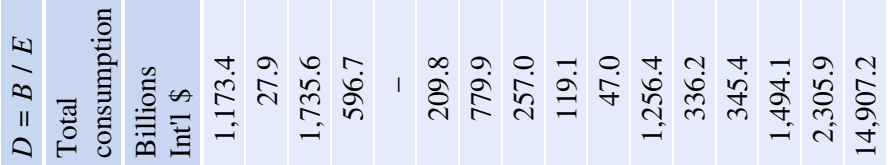

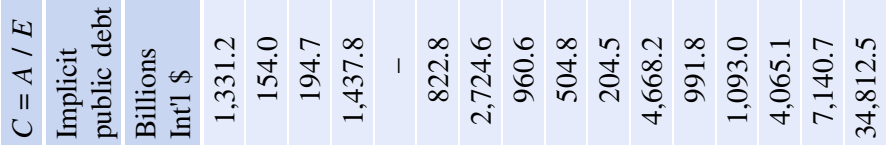

ص

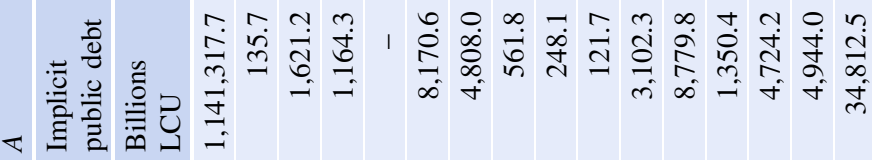

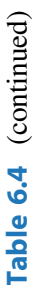

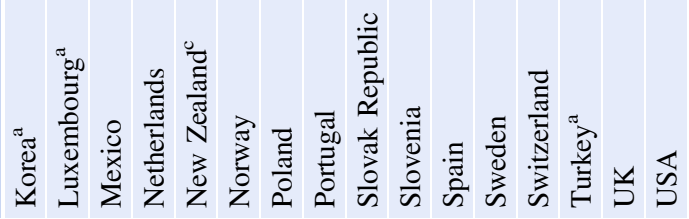




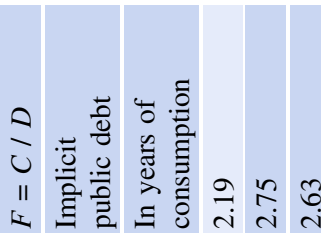

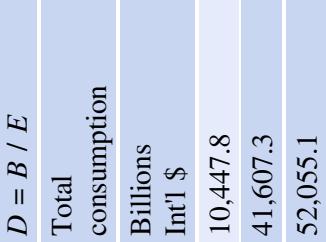

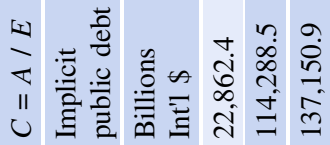



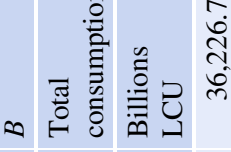

t)

ซ)

$\dot{0}$

छ

茂

$\approx$ i

एँ

年

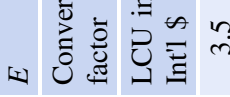

Sิ

范

芑已

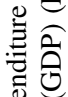

产

.

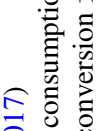

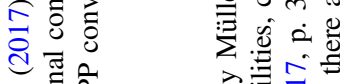

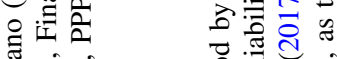

的的 ठ

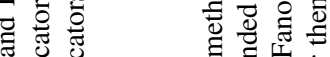



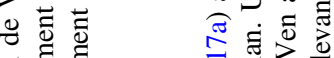

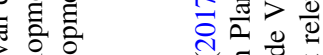

) 0 을

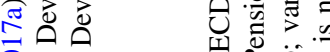

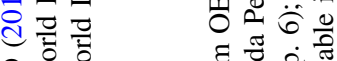

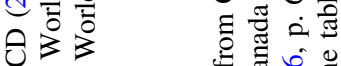

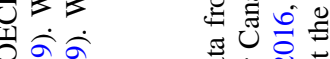

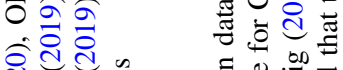

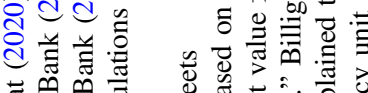

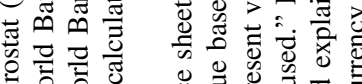

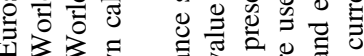

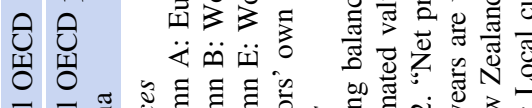

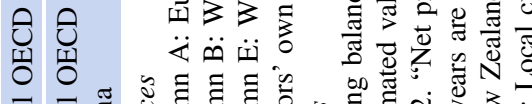

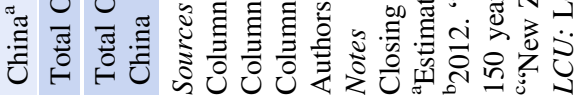


and column B the total consumption of each of the countries in 2015 in the respective local currency.

For the purpose of determining an aggregate value for the region as whole, the individual country figures for implicit public debt (column C) and total consumption (column D) are converted into international dollars (World Bank purchasing power parities). Column F shows implicit public debt in years of total consumption for each country. Luxembourg and Austria have the highest figures at 5.5 times and five times their total annual consumption, respectively. The lowest figures are found for Mexico (0.1 times) and Denmark (0.4 times). Germany's implicit public debt from the retirement system is equivalent to 3.6 times total annual consumption. The figures for the USA and China are equivalent to 2.3 times and 2.2 times their total annual consumption respectively. If we place aggregate implicit public debt in international dollars in relation to aggregate total consumption in international dollars, we obtain the result that implicit public debt from retirement systems in the OECD countries at a positive discount rate is equivalent to 2.75 times total annual consumption. Implicit public debt from retirement systems in the OECD plus China region is equivalent to 2.63 times total annual consumption.

\section{Implicit Retirement-Related Public Debt at a Real Discount Rate of Zero}

In Sect. 6.1.6, we showed in detail why we will be calculating private assets in the form of net public debt at a real interest rate of zero. We will now undertake an estimation of retirement-related implicit public debt, in which we do not-like in the official estimates - assume a nominal interest rate of $5 \%$ or a real rate of $3 \%$ for the European countries and a nominal interest rate of $5 \%$ or a real rate of $2.5 \%$ for the USA. Since the zero percent interest rate scenario is relevant for our purposes, in a next step, we use an extrapolation method to calculate the present value of retirement-related liabilities on the basis of a real rate of zero. We first undertake this calculation only for the Eurostat countries, since more data is available to us for these countries. Using a simple procedure, we will then transfer the results obtained to the other countries.

\section{Extrapolation Procedure}

On the basis of the deliveries of the national statistical offices, Eurostat (the statistical office of the European Union) has compiled data on public retirement benefit claims that will come due in the future for most of the European countries. We symbolize the real temporal progression of these claims in a given country as $F(t)$. The present value of these claims $G$ at a real discount rate $r$ is given, then, by

$$
G(r)=\int_{0}^{\infty} e^{-r t} F(t) d t
$$


If we differentiate with respect to $r$, we obtain

$$
\frac{d G}{d r}=-\int_{0}^{\infty} t e^{-r t} F(t) \mathrm{d} t
$$

The percentage rate of change of $G$ due to a marginal increase in the interest rate is thus

$$
\frac{d G / d r}{G}=\frac{-\int_{0}^{\infty} t e^{-r t} F(t) d t}{\int_{0}^{\infty} e^{-r t} F(t) d t}=-S(r)
$$

whereby $S(r)$ is the temporal "center of gravity" of the future payments.

The national statistical offices are required to perform so-called sensitivity analyses (Haug 2018, p. 86). In these analyses, they calculate present values of entitlements for a higher and a lower annual interest rate than in the base case scenario ( $5 \%$ nominal rate $=3 \%$ real rate).

Eurostat shows the level of $G(r)$ for $r=2,3$ and 4\%. For Germany, for example, the results are 8,281,610 million euros at $r=2 \%, 6,843,920$ million euros at $3 \%$ and 5,760,220 million euros at $r=4 \%$. Based on these figures, we can estimate that the temporal center of gravity at $r=2 \%$ is around 21 years and at $r=3 \%$ around 18.8 years.

We can now differentiate the temporal center of gravity $S(r)$ with respect to $r$. In so doing, we obtain:

$$
\begin{aligned}
\frac{d S}{d r} & =\frac{\left[\int_{0}^{\infty} e^{-r t} F(t) d t\right] \int_{0}^{\infty}-t^{2} e^{-r t} F(t) d t+\left[\int_{0}^{\infty} t e^{-r t} F(t) d t\right]^{2}}{\left[\int_{0}^{\infty} e^{-r t} F(t) d t\right]^{2}} \\
& =- \text { Variance }\left\{e^{-r t} F(t)\right\}<0
\end{aligned}
$$

We thus find that $S(r)$ increases when $r$ falls. The numbers of the statistical offices implicitly provide an approximation of $d s / d r$, inasmuch as $G$ is reported for three different values of $r$. We thus obtain $S(2 \%) \approx(G(2 \%)-G$ $(3 \%)) / G(3 \%)$ and $S(3 \%) \approx(G(3 \%)-G(4 \%)) / G(4 \%)$. By subtraction we arrive at an estimate for $d s / d r$.

$$
d S / d r \approx 100(S(3 \%)-S(2 \%))
$$

We now use this estimate of the first derivative $d S / d r$ for a linear extrapolation.

$$
\begin{aligned}
S(1 \%) & \approx S(2 \%)-1 / 100 d S / d r \approx S(2 \%)+((S 2 \%-S(3 \%)) \\
& =2 S(2 \%)-S(3 \%)
\end{aligned}
$$


and

$$
\begin{aligned}
S(0 \%) & \approx S(1 \%)-1 / 100 d S / d r \approx S(1 \%)+(S 1 \%-S(2 \%) \\
& =2 S(1 \%)-S(2 \%)
\end{aligned}
$$

We then extrapolate the values for $G$ from these estimates for $S$ using the equation

$$
d G / d r=-G S(r)
$$

If we only had the value of $G$ for two interest rates $r$, then we would have been able to perform a linear extrapolation of $G$. This would, however, have been less precise than proceeding by way of the linear extrapolation of $\mathrm{S}$, for which the value of $G$ for three values of $r$ is required. In our case, we are, in a sense, using the first and the second derivate of $G$ with respect to $r$.

For the other countries, for which we do not have data on present values of retirement benefit entitlements, we estimate the values by taking the change in the average value of the implicit public debt, as expressed in years of total consumption, that results from using the zero interest rate scenario as opposed to the $3 \%$ scenario for the 20 Eurostat countries that provide such data and then applying it also to them. ${ }^{18}$ In the extrapolation for the zero interest rate scenario, the implicit public debt of the 25 countries for which we have data on the present value of retirement benefits amounts, on average, to 5.19 times their respective annual consumption. Using a real discount rate of $3 \%$, implicit retirement-related public debt for these countries is, on average, only 2.79 years of total consumption. In the zero interest rate scenario, the implicit public debt of these 25 countries is thus 1.86 times higher than in the $3 \%$ scenario. This multiplier is now applied to the individual country figures for the remaining nine countries ${ }^{19}$ in column $\mathrm{A}$ in Table 6.4, in order to generate the corresponding entries in column A of Table 6.5.

Table 6.5 shows the results obtained for all the countries of the OECD plus China region at a discount rate of zero percent. The structure of Table 6.5 is like that of Table 6.4. Hence, following the table, we can move on directly to the overall result for the region as a whole.

The consequence of assuming a discount rate of zero percent is that retirementrelated implicit public debt increases considerably for all the countries. On average, there is nearly a doubling of the amount as compared to the base case scenario using

\footnotetext{
${ }^{18}$ Denmark and Sweden did not report data for present values of retirement benefit entitlements except in the baseline scenario. We therefore had to estimate values for these two countries. In doing so, we applied the average change in the present value of entitlements resulting from zero percent interest in the other 20 Eurostat countries. This is exactly how we proceeded in the case of the three non-European OECD countries: the USA, Mexico and Israel.

${ }^{19}$ As mentioned above, there are no comparable retirement programs or "social insurance pension schemes" in New Zealand. Therefore, we only consider 34 out of 35 countries in the OECD plus China region in our estimations for implicit retirement-related public debt.
} 


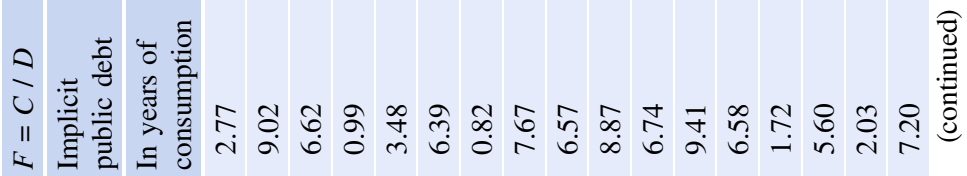

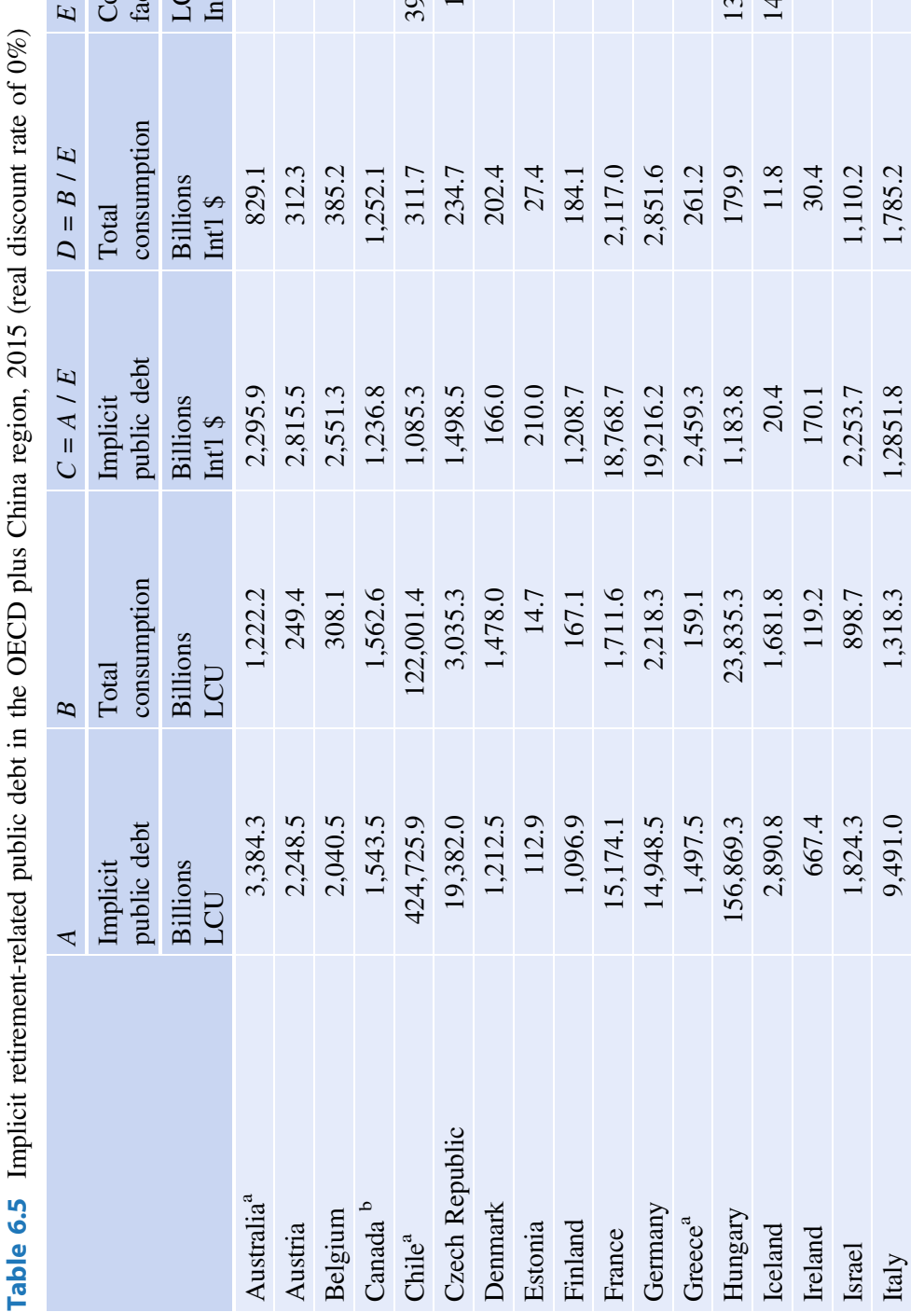




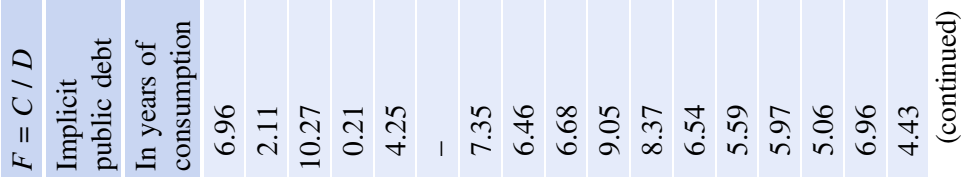

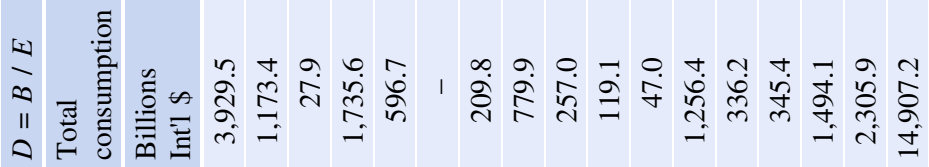

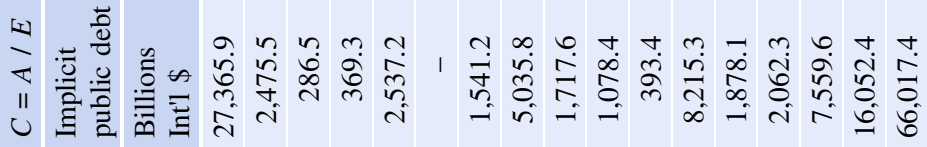

•

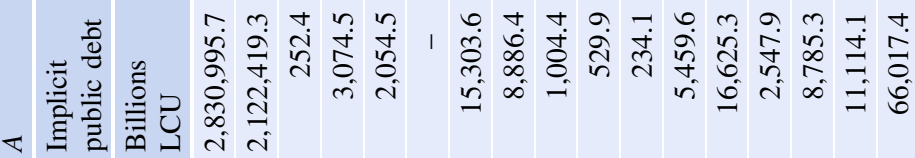

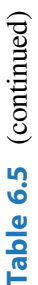

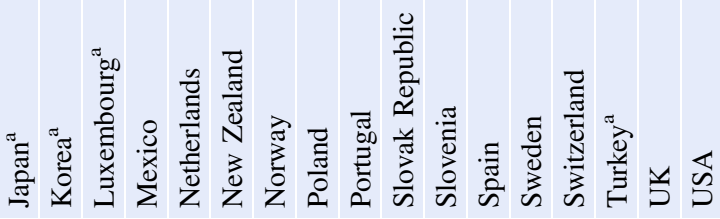



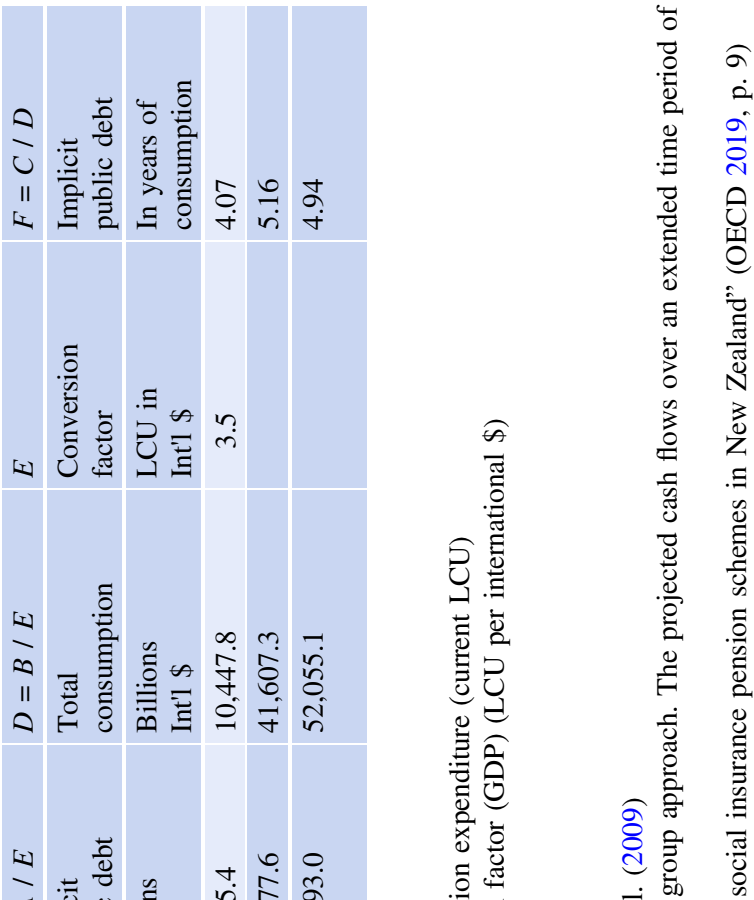

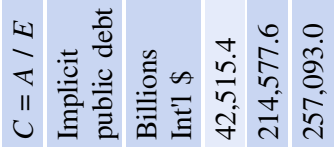

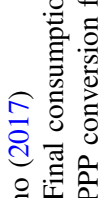

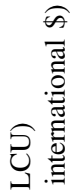

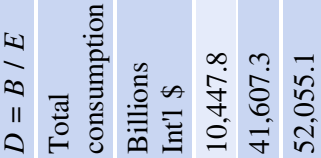

离

氖

产

产

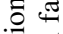

要

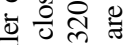

官它总 b: I

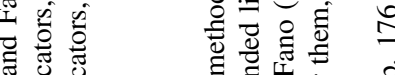

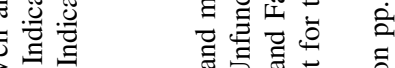

๑ ส

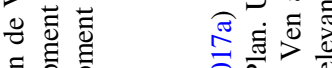
흔 흥 흥 बis

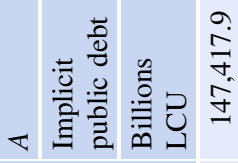
을 은

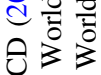
प्ञ $\dot{\sigma} \dot{\sigma}$ ब월



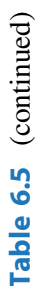

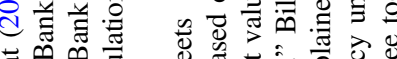

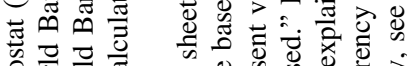

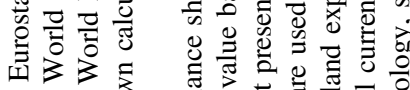

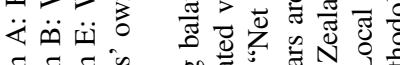

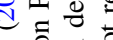

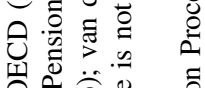

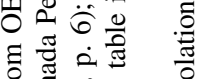
范 胥

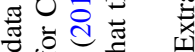
an

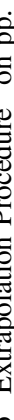

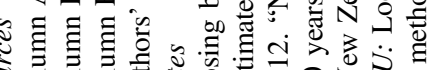


a real rate of $3 \%$. In the base case scenario, retirement-related implicit public debt in 2015 was about 2.7 times annual consumption in the OECD countries and 2.6 times annual consumption in the OECD plus China region as a whole (cf. Table 6.4). Now, at a real discount rate of zero percent, retirement-related implicit public debt in the OECD countries comes to slightly more than five-times total annual consumption. If we add China, then retirement-related implicit public debt (including the pension claims of civil servants and other public sector employees) in the OECD plus China region as a whole is 4.9 times total annual consumption - thus not so far from the OECD average. The overall result is especially heavily influenced by the big economies of the USA and China. In both countries, implicit retirement-related public debt as a percentage of annual consumption is below the OECD average of 5.2 years of consumption. In the zero interest rate scenario, we calculate retirement-related implicit public debt for the USA of about 4.4 times and for China about 4 times their respective annual consumption (cf. Table 6.5, column F).

We thus estimate that, for 2015, private sector wealth deriving from the public retirement system in the OECD plus China region is the equivalent of about 490 percent of annual consumption.

\subsubsection{Public Health Insurance}

Public health insurance also adds to implicit public debt. This is because a large part of health-related expenses are typically incurred in old age, but, unlike in private health insurance, no age-group-specific old-age provision funds are formed, as we have discussed in greater detail in Sect. 6.1.4. For estimating the implicit public debt arising from public health insurance, no data comparable to that for the public retirement system is available to us. Moreover, the 2008 SNA and the ESA 2010 do not provide for determining the present values of entitlements arising from public health insurance as part of the national accounts.

Since, along with nursing care insurance, public or national health insurance also contributes significantly to implicit public debt, we do not want to forego making a rough estimate of its magnitude. ${ }^{20}$ The reason for this is that a large part of healthcare expenditures are typically incurred in the final stages of a beneficiary's life. But, unlike private insurers, public health insurance systems usually do not form any reserves for younger beneficiaries. Hence, there is a similarity to the pay-as-you-go retirement system with respect to the absence of a reserve fund, and

\footnotetext{
${ }^{20}$ According to a study by Germany's Council of Economic Experts (SVR 2011), the public retirement system accounted for around 71\% of Germany's implicit public debt in 2011. Public health insurance and nursing care insurance together accounted for $26 \%$. Unemployment insurance, which we will not be taking into account, contributed just under $3 \%$. But the focus of the Council in estimating the implicit public debt arising from the various branches of the social security system was, above all, the sustainability of public finances. Moreover, the methodology used evidently did not follow the ADL principle and hence was different from ours. Therefore, the calculations of implicit public debt of the Council are not suitable for our purposes.
} 
public health insurance also involves implicit public debt. Like in the case of the retirement system, this implicit public debt is found by capitalizing future payments arising from the claims of beneficiaries enrolled in public health insurance and nursing care insurance. ${ }^{21}$

In the absence of international data, we will have to use an estimate for Germany as a guide when subsequently determining the value of implicit public debt arising from public health and nursing care insurance in the OECD plus China region. In so doing, we will make the highly simplifying assumption that a similar type of public health insurance system exists in the other 34 countries of the OECD plus China region as exists in Germany. This allows us also to estimate the implicit public debt from health insurance for the other countries by analogy with Germany. We will take into account here the different levels of healthcare expenditure by the relevant public agencies in the individual countries relative to their respective GDP. We are well aware that the estimate that we make for the OECD plus China region as a whole using this simple procedure can only serve as a rough approximation of the actual magnitude.

\section{Public Health and Nursing Care Insurance in Germany}

If, as we have suggested, a pay-as-you-go social security scheme can be regarded as a kind of funded scheme without a reserve fund, then the task at hand is to estimate the size of the missing reserve fund for public health and nursing care insurance. For we understand the missing reserve fund as an expression of the implicit public debt arising from this insurance. We begin with Germany.

Unlike the pay-as-you-go public health and nursing care insurance, private health insurance providers in Germany form old-age provisions for their policyholders. In the glossary in its 2015 report, Germany's Association of Private Health Insurance Providers (PKV) explains the concept of "old-age provision funds" as follows:

"Old-age provisions: private health and nursing care insurance providers form old-age provisions in anticipation of the fact that with increasing age, healthcare benefit claims also increase. Insurance premiums are calculated in such a way that they are higher in younger years than the benefits actually claimed. The difference is initially invested in old-age provision funds. When, in later years, the calculated costs of health care are then greater than the premium paid, the shortfall is made up by withdrawals from the old-age provisions..." (PKV 2017, p. 118).

These provisions thus represent a reserve fund for covering future healthcare costs of privately insured persons that are predominantly incurred in old age. In order to make adequate provision, in light of predicted demographic changes and expected additional expenditure, private health insurance companies allocate a certain amount to their old-age provisions each year, so that the reserve fund can

\footnotetext{
${ }^{21}$ Since 2010, however, the public insurance providers and their associations in Germany are legally required "to build up a sufficient capital fund, by the end of 2049 at the latest, to be able to meet their old-age benefit obligations (both pensions and health and nursing care benefits)" (Bundesversicherungsamt 2017, p. 2).
} 
Table 6.6 Calculation of hypothetical old-age provisions for public health and nursing care insurance in Germany

\begin{tabular}{|c|c|c|c|c|c|}
\hline Health insurance & 2005 & $\ldots$ & 2014 & 2015 & 2016 \\
\hline 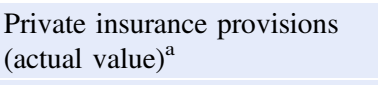 & 88,748 & $\ldots$ & 177,706 & 189,045 & 200,165 \\
\hline $\begin{array}{l}\text { Private insurance premium } \\
\text { income }^{\mathrm{a}}\end{array}$ & 24,748 & $\ldots$ & 32,642 & 32,822 & 33,159 \\
\hline $\begin{array}{l}\text { Ratio of private insurance } \\
\text { provisions to premium income }\end{array}$ & 3.59 & $\ldots$ & 5.44 & 5.76 & 6.04 \\
\hline $\begin{array}{l}\text { Public insurance premium } \\
\text { income }^{\mathrm{a}}\end{array}$ & 145,740 & $\ldots$ & 204,240 & 212,560 & 224,350 \\
\hline  & 522,625 & $\ldots$ & $1,111,892$ & $1,224,267$ & $1,354,281$ \\
\hline Nursing care insurance & 2005 & $\ldots$ & 2014 & 2015 & 2016 \\
\hline $\begin{array}{l}\text { Private insurance provisions } \\
{\text { (actual value })^{\mathrm{a}}}\end{array}$ & 14,623 & $\ldots$ & 28,487 & 31,038 & 32,555 \\
\hline $\begin{array}{l}\text { Private insurance premium } \\
\text { income }^{\mathrm{a}}\end{array}$ & 2,038 & $\ldots$ & 2,913 & 3,205 & 3,281 \\
\hline $\begin{array}{l}\text { Ratio of private insurance } \\
\text { provisions to premium income }\end{array}$ & 7.18 & $\ldots$ & 9.78 & 9.69 & 9.92 \\
\hline $\begin{array}{l}\text { Public insurance premium } \\
\text { income }^{\mathrm{a}}\end{array}$ & 17,490 & $\ldots$ & 25,910 & 30,690 & 32,030 \\
\hline 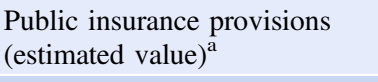 & 125,526 & $\ldots$ & $2,3,423$ & 297,259 & 317,856 \\
\hline $\begin{array}{l}\text { Ratio of total provisions to } \\
\text { current consumption }\end{array}$ & 2005 & $\ldots$ & 2014 & 2015 & 2016 \\
\hline Total consumption ${ }^{\mathrm{a}}$ & $1,751,547$ & $\ldots$ & $2,158,105$ & $2,218,284$ & $2,291,063$ \\
\hline $\begin{array}{l}\text { Total hypothetical provisions: } \\
\text { public health and care } \\
\text { insurance }{ }^{\mathrm{a}}\end{array}$ & 648,152 & $\ldots$ & $1,365,315$ & $1,521,526$ & $1,672,137$ \\
\hline $\begin{array}{l}\text { Hypothetical provisions in } \\
\text { years of total consumption }\end{array}$ & 0.37 & $\cdots$ & 0.63 & 0.69 & 0.73 \\
\hline
\end{tabular}

\section{Sources}

PKV $(2015,2016)$

The Information System of the Federal Health Monitoring, www.gbe-bund.de

World Bank (2019). World Development Indicators, Final consumption expenditure (current LCU)

Authors' own calculations

Notes

${ }^{\mathrm{a}}$ In millions of euros

Public health insurance premium income without federal funding

Private health insurance premium income from full health insurance, supplementary insurance to public health insurance coverage, per diem sickness insurance, hospitalization per diem insurance Private care insurance premium income from nursing care insurance, complementary nursing care insurance, subsidized nursing care insurance (since 2013) 
constantly grow (cf. Table 6.6). In 2015, according to the association, the old-age provisions of private health insurance providers came to around 189 billion euros. Up to 2015, old-age provisions of around 31 billion euros were formed for private nursing care insurance.

In what follows, we estimate hypothetical old-age provisions for public health and nursing care insurance in Germany. To this end, we first determine the ratio of the old-age provisions of the private health insurance providers to their income from insurance premiums. As Table 6.6 shows, in 2005, the old-age provisions of private health insurance providers came to around 3.6 times their annual income from insurance premiums. Over the years, this ratio has constantly and significantly increased. By 2016, the amount of the old-age provisions had grown to six times the income from premiums. The ratio of old-age provisions to premium income is even far greater in the case of private nursing care insurance. Whereas in 2005, old-age provision funds amounted to seven times the premium income of private nursing care insurance providers, this figure had risen to ten times by $2016 .^{22}$

In order to determine the hypothetical old-age provisions of public health and nursing care insurance, we now make a highly simplifying assumption. We assume that the ratio of old-age provisions to premium income is the same in the two sorts of public insurance as in private health insurance. This is a gross simplification, to which various objections can be raised. These objections, however, go in different directions. An argument for assuming a higher ratio of old-age provisions to premium income for the public insurance providers is that private insurers generally cover the "better risks" and can hence expect relatively lower expenditures for beneficiaries in old age. An argument for assuming a lower ratio of old-age provisions to premium income for the public insurance providers is that persons enrolled in public insurance schemes tend to pay lower premiums for their insurance in old age than persons with private insurance usually have to do. Since, in the absence of data, we have here to make an estimate, we regard the assumption of an equal ratio of old-age provisions to premium income in both private and public health and nursing care insurance as justifiable.

As can be seen in Table 6.6, in 2015, the public health insurance system in Germany collected around 212.6 billion euros in premiums. Assuming a ratio of old-age provisions to premium income of 5.76, there were hypothetical old-age provisions in public health insurance of around 1224.3 billion euros in 2015 . The premiums that were collected in 2015 for public nursing care insurance came to around 30.7 billion euros. If we apply the 2015 multiplier of 9.69 , we get hypothetical old-age provisions for public nursing care insurance worth approximately 297.3 billion euros.

We estimate that the combined hypothetical old-age provisions for public health and nursing care insurance in Germany in 2015 were around 1521.5 billion euros. This is equivalent to 0.69 years of total consumption in 2015. As Fig. 6.4 shows, hypothetical old-age provisions, as expressed in years of total consumption, have

\footnotetext{
${ }^{22}$ In accordance with actuarial principles, this increase must be attributable to increased life expectancy and to a lower discount rate.
} 


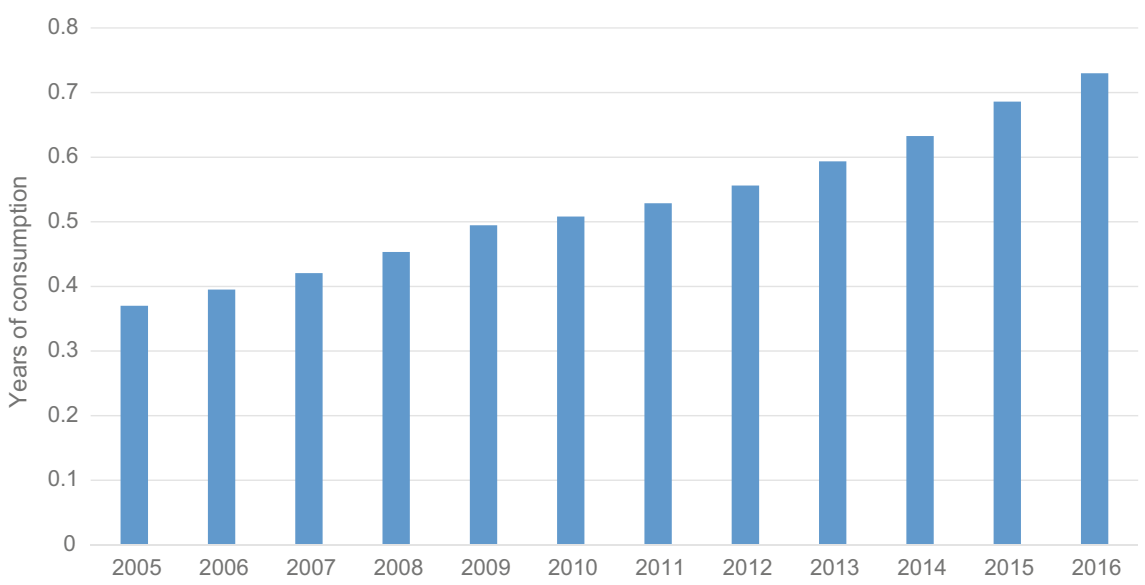

Fig. 6.4 Hypothetical old-age provisions for public health and nursing care insurance in years of total consumption. Source Authors' own calculations

risen significantly since 2005 . In 2005 , they amounted to only 0.37 times total annual consumption, in 2010 to half of annual consumption, and in 2016 to nearly three-quarters of annual consumption. In light of the clear rise in the numbers and in anticipation of the trend continuing in the future, the considerations set out in this book lead us to expect a further rapid increase in implicit public debt due to public health and nursing care insurance. Since, however, we have chosen 2015 as reference year in this book, in what follows, we merely assume 0.69 times total annual consumption for public debt arising from public health and nursing care insurance in Germany. This figure, moreover, forms the basis for applying the German result to the other countries and hence for the estimate of implicit public debt from health and nursing care insurance in the OECD plus China region as a whole.

\subsubsection{Implicit Public Debt from Health Insurance in the OECD Plus China Region}

In estimating implicit retirement-related public debt for those nine countries without OECD data on retirement benefit entitlements, we used the ratio of current benefit expenditure to GDP for each country. We want now to proceed in an analogous fashion for health and nursing care insurance. The OECD (2017b) divides the healthcare expenditure of the countries on which it reports into "voluntary/ out-of-pocket" and "government/compulsory" expenditure. By the latter category, the OECD understands expenditure that is undertaken, on the one hand, by public agencies, but also, on the other, by private health insurance providers. ${ }^{23}$

\footnotetext{
${ }^{23}$ In most OECD countries, health insurance is compulsory. Since one has either to be insured under the public health insurance scheme or by a private insurance provider, the OECD also classifies private health insurance as "government/compulsory health expenditure" (OECD 2017b).
} 
Since what is of interest for us is the relationship of private persons to the state, in what follows, only public healthcare expenditure will be used. ${ }^{24}$ Private health insurance expenditure will thus be purged from the OECD "government/ compulsory" figure, in order to arrive at public healthcare expenditure. ${ }^{25}$

In 2015 , approximately 252.4 billion euros were spent on public health services in Germany. ${ }^{26}$ This is equivalent to around $11 \%$ of total annual consumption in the same year. If we now place the implicit public debt arising from German public health and nursing care insurance in 2015 (1521.5 billion euros) in relation to public healthcare expenditure, we obtain a ratio of 6.028. This multiple of current public healthcare expenditure is for us a proxy for the hypothetical old-age provisions of public health and nursing care insurance. We are thus, in principle, applying the same method of estimation that we used to infer implicit retirement-related public debt from current retirement benefit expenditure in the previous section and that was derived from the calculations of Müller et al. (2009).

Hence, we assume that the implicit public debt arising from health and nursing care insurance is equivalent to approximately six times a country's public healthcare expenditure. For simplicity's sake, we refer to the ratio of the flow variable, healthcare expenditure, to the stock variable, hypothetical old-age provisions or the hypothetical capital fund, as the "capitalization factor." In what follows, public health and public nursing care insurance, as well as other forms of health-related public insurance (e.g., accident insurance), will simply be called "public health insurance" for short. Thus, for implicit public debt $D I$ arising from public health insurance, $D I_{G}^{H}$, in Germany,

$$
D I_{G}^{H}=H E_{G} \cdot C F_{G}^{H}
$$

holds. $H E_{G}$ stands here for public healthcare expenditure in Germany, which amounted to around $11 \%$ of total consumption in 2015 .

Using the German figures for 2015, the "capitalization factor" (CF) from public health insurance is:

$$
C F_{G}^{H}=\frac{D I_{G}^{H}}{H E_{G}}=\frac{0.61}{0.11}=6.028
$$

\footnotetext{
${ }^{24}$ This includes health-related expenditure of the public health insurance plan, public nursing care insurance, the public retirement plan (especially for rehabilitation), public accident insurance and expenditure from public budgets (in particular, investment in hospitals) (Bundesministerium für Gesundheit 2018).

${ }^{25}$ In 2015 , private health insurance expenditure amounted to approximately 30.5 billion euros; this is equivalent to $8.9 \%$ of total health care expenditure in Germany. Together with employer expenditure (above all, for income replacement in the case of illness and company health services) and voluntary healthcare expenditure of households and non-profit institutions, private healthcare expenditure accounted for somewhat more than one-quarter of total expenditure.

${ }^{26}$ Authors' own calculations using data from Bundesministerium für Gesundheit $(2018,2019)$, p. 129.
} 
We now assume that this ratio can also be applied to every other country $i$ in the OECD plus China region:

$$
C F_{G}^{H}=C F_{i}^{H}=C F^{H}
$$

The implicit public debt deriving from the public health insurance of a given country $i\left(\mathrm{DI}_{\mathrm{i}}^{\mathrm{H}}\right)$ can thus be calculated as:

$$
D I_{i}^{H}=H E_{i} \cdot C F^{H}
$$

The meanings of the symbols are as follows:

$D I_{G}^{H}, D I_{i}^{H}$ : implicit public debt from public health and nursing care insurance in years of total consumption in Germany and country $i$ respectively.

$H E_{G}, H E_{i}$ : Healthcare expenditure in years of total consumption in Germany and country $i$, respectively.

$C F_{G}^{H}, C F_{i}^{H}$ : "capitalization factor" for health and nursing care insurance in years of total consumption for Germany and country $i$, respectively.

We apply this "capitalization factor" of 6.028 for estimating implicit public debt from health and nursing care insurance to the other countries by multiplying the public healthcare expenditure of each of the countries in 2015 by this factor. An example for the USA can serve to illustrate the procedure. In 2015, the USA spent 2227.6 billion US dollars on health (OECD 2017b). Therefore,

2227.6 billion US dollars $\times 6.028=13,428.0$ billion US dollars. $^{27}$

Column D of Table 6.7 shows the implicit public debt calculated for each country using this procedure. For the purpose of aggregation, in the next step, both the implicit public debt and the total consumption of each country are converted from the respective local currency (LCU) into international dollars (purchasing power parities; cf. columns E and F) The aggregate implicit debt of all the countries divided by the aggregate total consumption of all the countries gives the overall result for the OECD countries and the OECD plus China region, respectively.

For the OECD countries, we estimate that implicit public debt from health and nursing care insurance is approximately $64 \%$ of total annual consumption. If we take China into account, then we obtain a figure of $57 \%$ of total annual consumption for the implicit public debt from health and nursing care insurance in the OECD plus China region.

\section{Implicit Public Debt: Present Value of Changes in Healthcare Expenditure in the OECD plus China Region, 2015-2050}

To test the plausibility of our results and the methodology underlying them, we want finally to present an alternative estimate based on data from the International Monetary Fund (IMF). In its report, the IMF notes that implicit public debt is of

\footnotetext{
${ }^{27}$ Discrepancy due to rounding.
} 


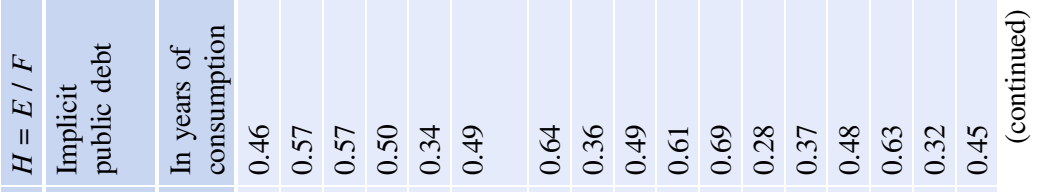

৩

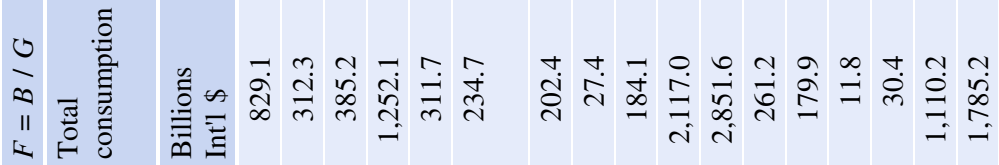

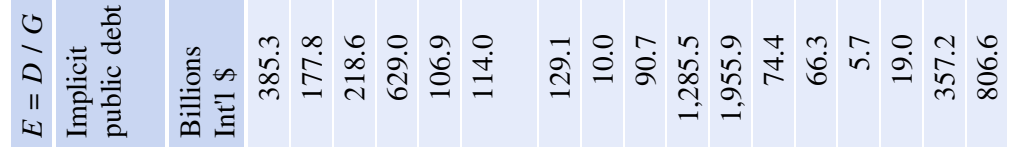
ㄱ.

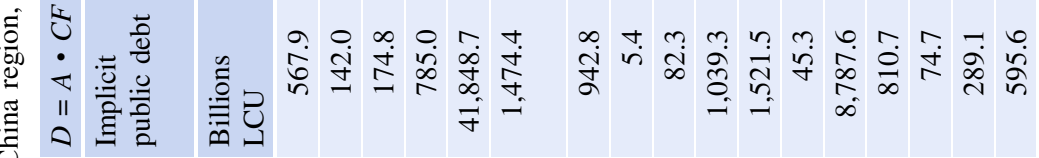
$\stackrel{\mathscr{2}}{2}$

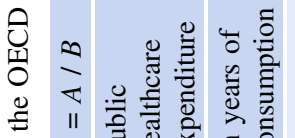




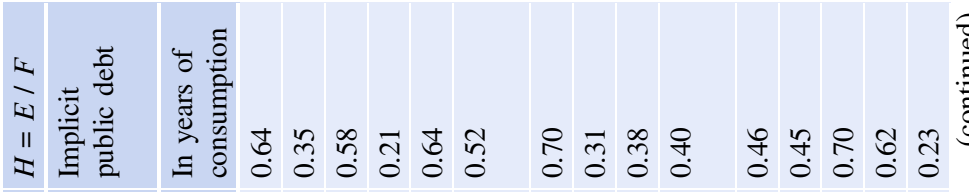

ن

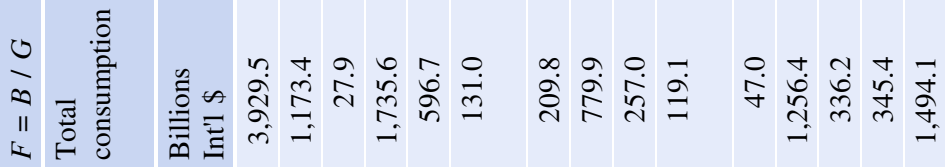

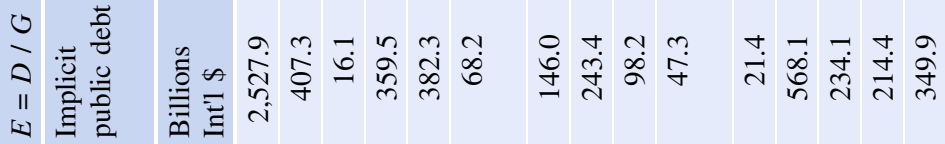

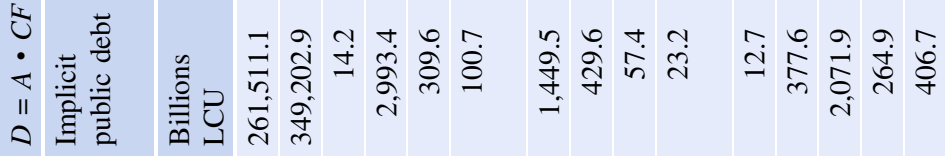

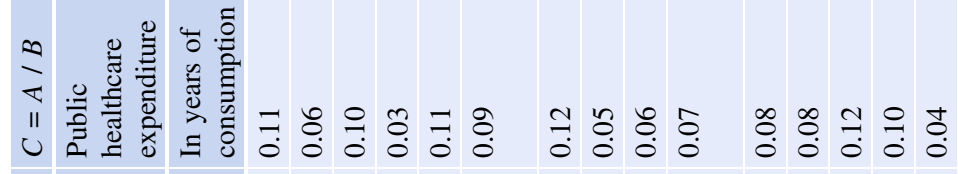

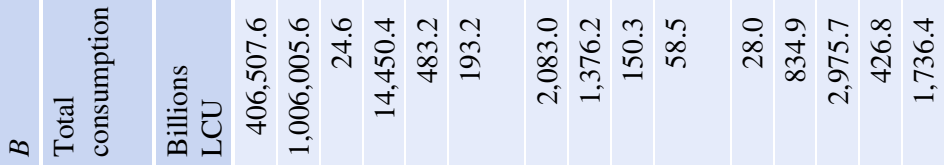

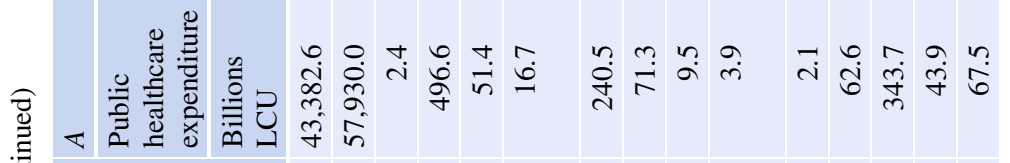
远

ชั

일

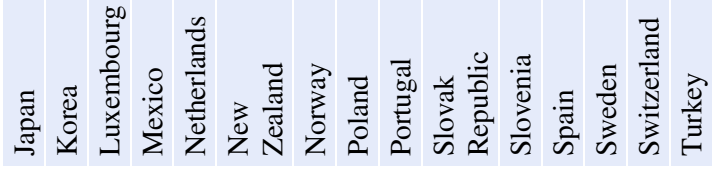




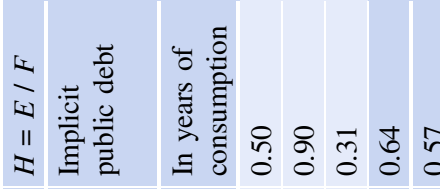

ธี

ט

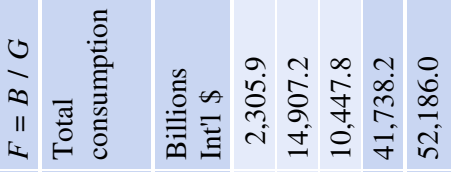

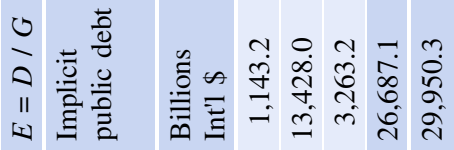

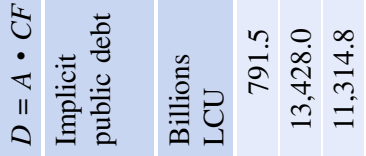
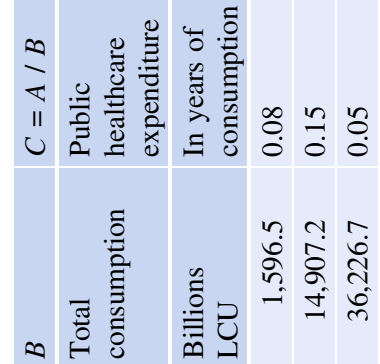

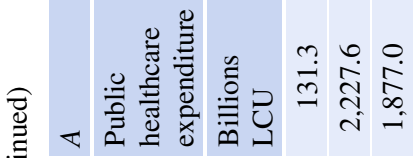

1)

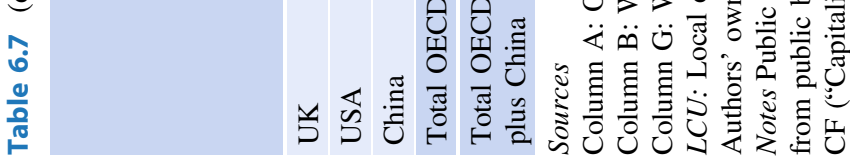


great significance, given the aging of the population in many of its member countries (IMF 2018b, p. 12).

In contrast to our methodology, which is based on the accrued-to-date-liabilities (ADL) principle that we have described in detail above, the IMF (2018b) attempts to estimate the present values that result from the changes in healthcare expenditure in the IMF member countries that are projected to take place between 2015 and 2050. Future revenue is also taken into account here, as is usual in the Open Group Method that appears to have been used. ${ }^{28}$ These present values are given as a percentage of each country's GDP (cf. column A of Table 6.8). As can be seen in the table, the countries are facing very different present values. Switzerland $(116 \%)$ and the USA (122\%) especially stand out. ${ }^{29}$ A present value of $48 \%$ is calculated for Germany.

If we relate these individual present values of the countries of the OECD plus China region to their respective total annual consumption and aggregate them in the same way as has been done in Tables 6.2, 6.4, 6.5 and 6.7, then we obtain the following overall result. In accordance with the IMF data and methodology, the changes in healthcare expenditure that are projected for the OECD countries between 2015 and 2050 give rise to implicit public debt equivalent to just under one year of total consumption. For the OECD plus China region as a whole, the implicit public debt arising from changes in healthcare expenditure is estimated to be $91 \%$ of total annual consumption. Comparing these results with the results of the estimates that we have undertaken (OECD countries: $64 \%$ of total annual consumption; OECD plus China region: $57 \%$ of total annual consumption) shows that our approach has evidently not led to implausibly high estimates for implicit public debt from health insurance.

\subsubsection{Explicit and Implicit Public Debt in the OECD Plus China Region: Summary of Estimates}

Table 6.9 provides a concluding overview of all the figures on explicit and implicit public debt that have been calculated with zero percent interest rate in Sect. 6.2. We estimate that total public debt (the sum of explicit and implicit public debt) in the OECD is 6.72 times and in the OECD plus China area 6.26 times the respective total annual consumption. At 0.75 times total annual consumption, explicit debt, which has been calculated as net public debt, accounted for only a relatively small part of this. According to our estimates, implicit public debt in the OECD plus China region in 2015 came to 5.51 times total annual consumption. Implicit public

\footnotetext{
${ }^{28}$ The IMF does not provide any detailed information on methodology in its report. Like Germany's Council of Economic Experts in its expert opinion on demographic change (SVR 2011), the IMF's focus is clearly on analyzing the sustainability of public debt. Thus, the report states: "Taking a long-term view through the intertemporal balance sheet allows a comparison of current wealth against future fiscal pressures." On methodology, moreover, it specifies: "...the balance sheet is used to determine the long-term intertemporal net worth under current policies, combining discounted future flows of revenues and spending with the static balance sheet" (IMF 2018 b, p. 17 and p. 33).

${ }^{29}$ On the status of the US healthcare system, cf. Gaudette et al. (2015).
} 


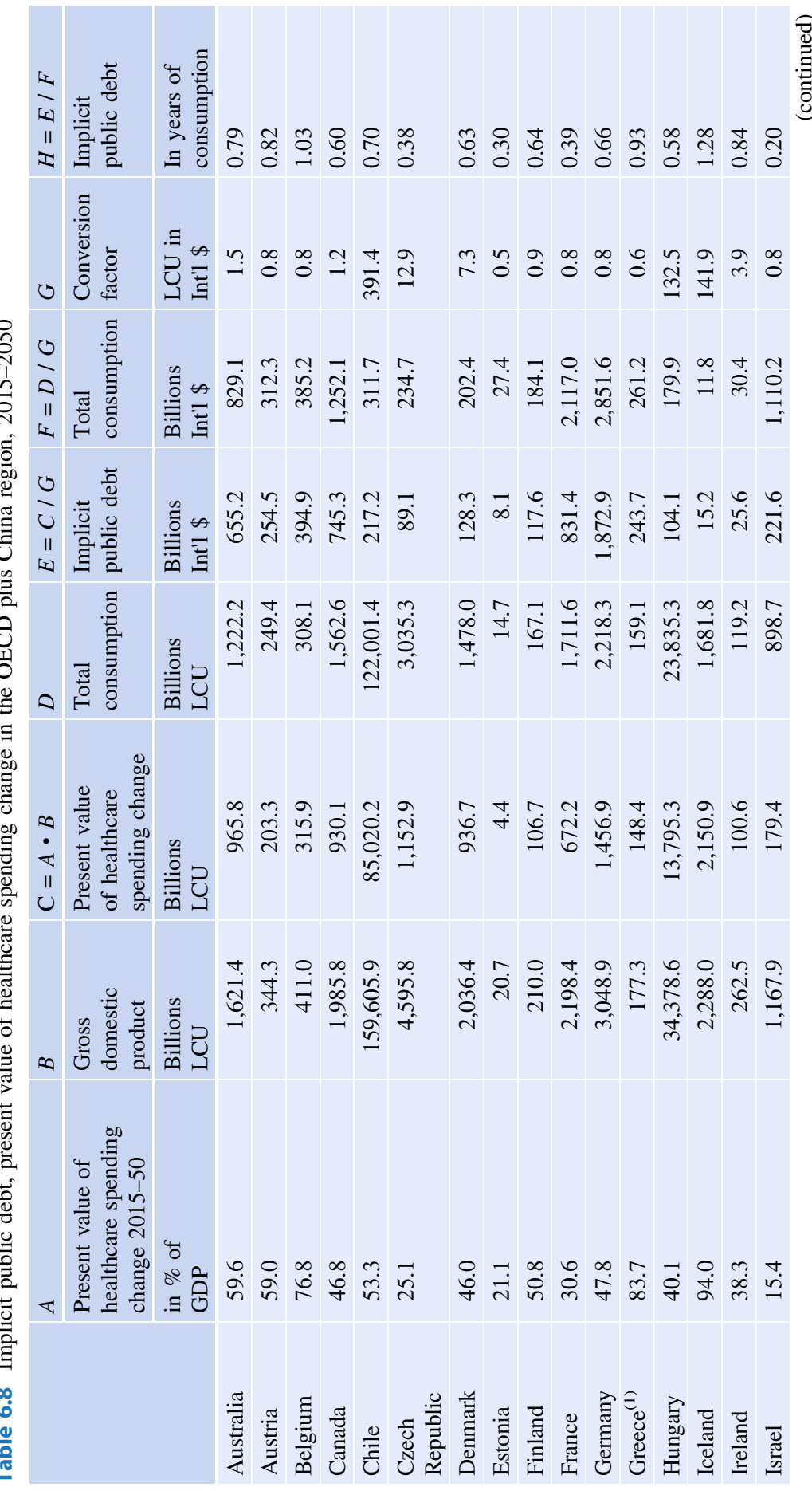




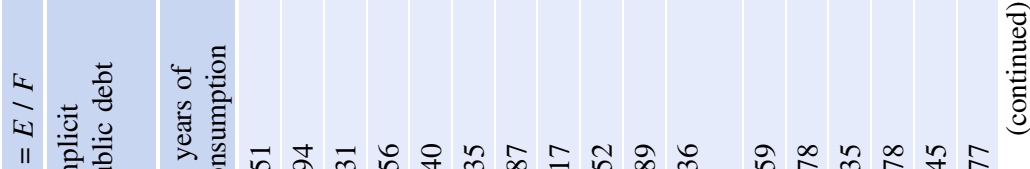

ن

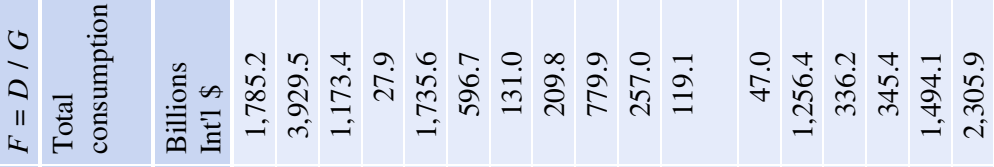

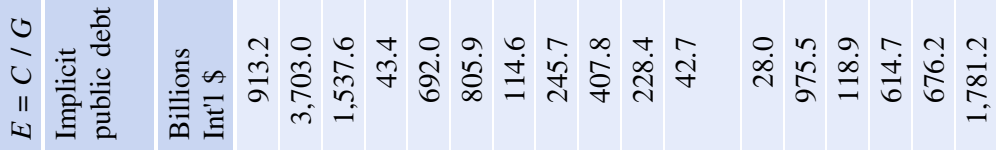

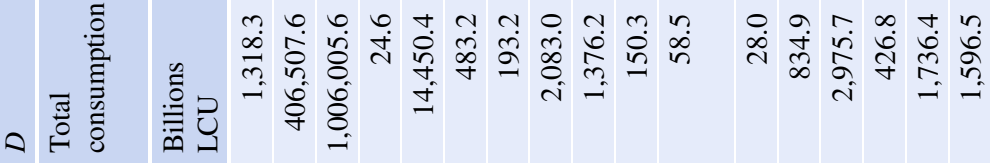

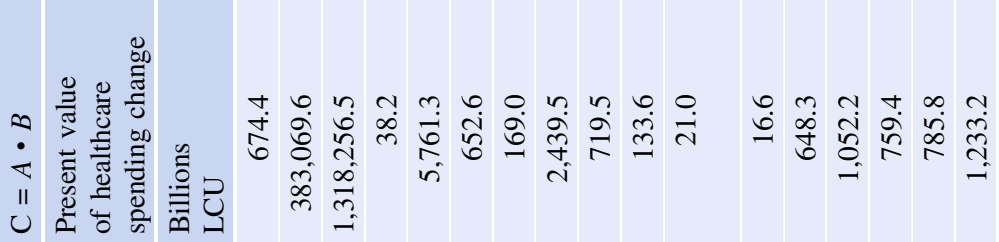



兽

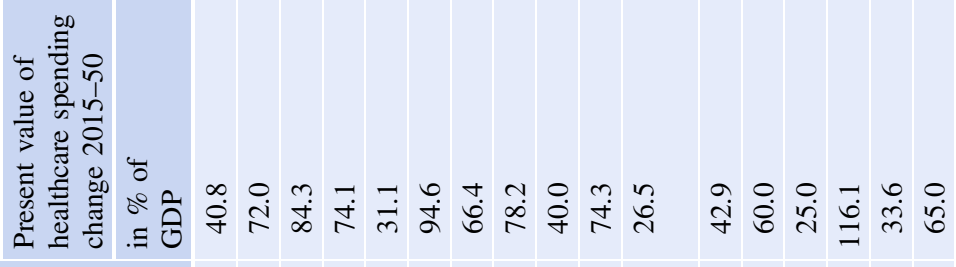

离






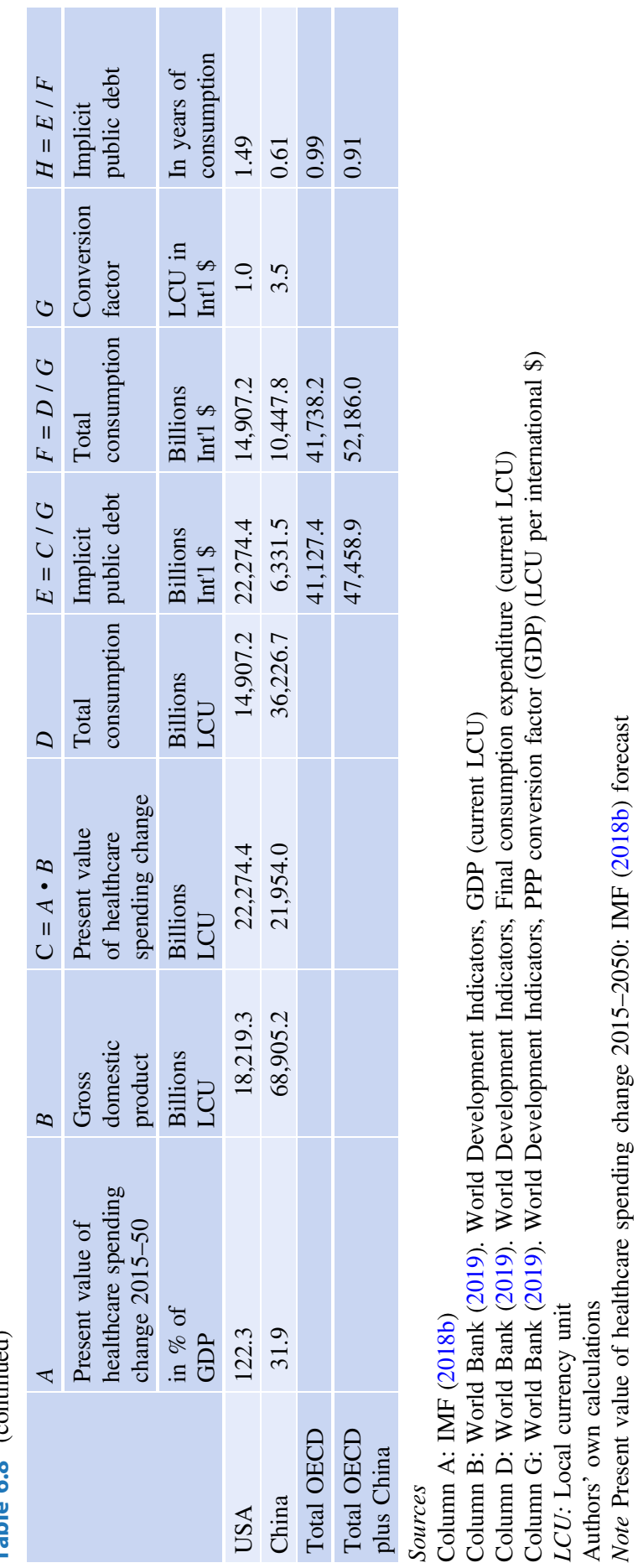


Table 6.9 Overview of the estimates of explicit and implicit public debt in the OECD plus China region, 2015

\begin{tabular}{|c|c|c|c|c|}
\hline \multicolumn{5}{|c|}{$\begin{array}{l}\text { Results of the empirical estimates of public debt in years of total consumption } \\
\text { (with zero percent interest rate) }\end{array}$} \\
\hline & USA & Germany & OECD & $\begin{array}{l}\text { OECD plus } \\
\text { China }\end{array}$ \\
\hline Explicit public debt & 0.98 & 0.70 & 0.92 & 0.75 \\
\hline Implicit public debt (pensions) & 4.43 & 6.74 & 5.16 & 4.94 \\
\hline $\begin{array}{l}\text { Implicit public debt (health and care } \\
\text { insurance) }\end{array}$ & 0.90 & 0.69 & 0.64 & 0.57 \\
\hline Total & 6.31 & 8.12 & 6.72 & 6.26 \\
\hline
\end{tabular}

Source Authors' own calculations

debt is thus much more significant for the claims of private persons on the state. By far the largest part of this debt derives from the public retirement system, for which we have calculated implicit public debt of $494 \%$ of total consumption in the OECD plus China region in 2015. A closer look at the table reveals that at $631 \%$, the US total public debt figure is about the average for both the OECD countries and the OECD countries plus China. Whereas, at $812 \%$ of annual consumption, the corresponding figure for Germany is significantly higher than these averages. The difference is especially pronounced for the public retirement system (180\% points above the total area average), while the US figure is about $50 \%$ points below the total area average (i.e., the OECD plus China). The situation is somewhat different for implicit public debt from public health and nursing care insurance. Both the USA and Germany have a higher implicit public debt from these sources than the total area average of $57 \%$ of total consumption. However, the USA has a higher figure than Germany at $90 \%$ as compared to $69 \%$ of total consumption.

\section{References}

Aghion, Philippe, Antonin Bergeaud, Timo Boppart, Peter J. Klenow and Huiyu Li. 2019. Missing Growth from Creative Destruction. American Economic Review 109 (8): 2795-2822.

Billig, Assia. 2016. Compiling the actuarial balance sheet for the Canada Pension Plan methodological overview. Presentation to the Eurostat/ILO/IMF/OECD Workshop on Pensions. Paris, 9.3.2016. http://www.osfi-bsif.gc.ca/Eng/Docs/OCA-Assia-Billig-03092016Slides.pdf. Accessed: 12 May 2019.

Board of Governors of the Federal Reserve System. 2020a. Enhanced Financial Accounts, State Pensions, State and Local Pension Funding Status and Ratios by State, 2002-2018. https:// www.federalreserve.gov/releases/z1/dataviz/pension/comparative_view/table/. Accessed: 12 December 2020.

Board of Governors of the Federal Reserve System. 2020b. Z1-Financial Accounts, L.119.b Federal Government Employee Retirement Funds: Defined Benefit Plans. https://www. federalreserve.gov/apps/fof/DisplayTable.aspx?t=l.119.b/. Accessed: 12 December 2020

Board of Trustees OASDI. 2016. The 2016 Annual Report of the Board of Trustees of the Federal Old-Age and Survivors Insurance and Federal Disability Insurance Trust Funds. Washington (D.C.): U.S. Government Publishing Office. 
Board of Trustees OASDI. 2020. The 2020 Annual Report of the Board of Trustees of the Federal Old-Age and Survivors Insurance and Federal Disability Insurance Trust Funds. Washington (D.C.): U.S. Government Publishing Office.

Braakmann, Albert, Jens Grütz and Thorsten Haug. 2007. Das Renten- und Pensionsvermögen in den volkswirtschaftlichen Gesamtrechnungen. Methodik und erste Ergebnisse. Wirtschaft und Statistik 12: 1167-1179.

Bundesministerium für Gesundheit. 2018. Daten des Gesundheitswesens 2018. Berlin: Bundesministerium für Gesundheit.

Bundesministerium für Gesundheit. 2019. Finanzierungsgrundlagen der gesetzlichen Krankenversicherung. Berlin: Bundesministerium für Gesundheit. https://www.bundesgesundheitsministerium. de/finanzierung-gkv.html. Accessed: 30 May 2019.

Bundesversicherungsamt. 2017. Leitfaden zur Altersrückstellungsverordnung für die gesetzlichen Krankenkassen und ihre Verbände, Version: 8 December 2017. https://www.bundesver sicherungsamt.de/fileadmin/redaktion/Krankenversicherung/Altersversorgungsverpflichtungen/ Leitfaden_KK-AltRueckV_Stand_8._12.2017.pdf. Accessed: 1 June 2019.

Economist. 2019. Public Pensions - State of Denial. 16 November 2019: p. 65-66.

European Commission, IMF, OECD, UN and World Bank. 2009. System of National Accounts 2008. https://unstats.un.org/unsd/nationalaccount/docs/SNA2008.pdf. Accessed: 2 April 2019.

Eurostat. 2013. European System of Accounts: ESA 2010. Luxembourg: Publications Office of the European Union.

Eurostat. 2020. Pensions in National Accounts (nasa_10_pens). https://ec.europa. eu/eurostat/ web/pensions/data/database. Accessed: 30 December 2020.

Freudenberg, Christoph. 2017. Alterssicherungssysteme in der Finanzierungsrechnung. In Die gesamtwirtschaftliche Finanzierungsrechnung. Revision und Anwendung in ökonomischen Analysen, Berliner Beiträge zu den Volkswirtschaftlichen Gesamtrechnungen, vol. 1, eds. Reimund Mink and Klaus Voy, 323-347. Marburg: Metropolis-Verlag.

Gaudette, Étienne, Bryan Tysinger, Alwyn Cassil and Dana P. Goldman. 2015. Health and Health Care of Medicare Beneficiaries in 2030. Forum for health economics \& policy 18 (2): 75-96.

Haug, Thorsten. 2018. Berechnung der Pensions- und Rentenanwartschaften in den volkswirtschaftlichen Gesamtrechnungen. Berechnungsmethodik und Ergebnisse. Wirtschaft und Statistik 2: 77-90.

Hellwig, Martin. 2019. Target-Falle oder Empörungsfalle - Zur deutschen Diskussion um die Europäische Währungsunion. Perspektiven der Wirtschaftspolitik 19 (4): 345-382.

Holzmann, Robert, Robert Palacios and Asta Zviniene. 2004. Implicit pension debt: Issues, measurement and scope in international perspective. Social Protection Discussion Paper No. 0403. Washington (D.C.): World Bank.

Holzmann, Robert. 1998. Financing the Transition to Multi-Pillar. Social Protection Discussion Paper No. 9809. Washington (D.C.): World Bank.

IMF (International Monetary Fund). 2013. Public sector debt statistics: guide for compilers and users. 2nd ed. Washington (D.C.): International Monetary Fund.

IMF (International Monetary Fund). 2016. Implementing Accrual Accounting in the Public Sector. Technical Notes and Manuals. Prepared by Joe Cavanagh, Suzanne Flynn, and Delphine Moretti. Washington (D.C.): International Monetary Fund.

IMF (International Monetary Fund). 2018a. Fiscal Monitor. Capitalizing on Good Times. April 2018. Washington (D.C.): International Monetary Fund.

IMF (International Monetary Fund). 2018b. Fiscal Monitor. Managing Public Wealth. October 2018. Washington (D.C.): International Monetary Fund.

IMF (International Monetary Funds). 2018c. Global Debt Database. https://www.imf.org/ / media/Files/Publications/fiscal-monitor/2018/April/data/gdd121318.ashx?la=en. Accessed: 27 May 2019.

Kaier, Klaus and Christoph Müller. 2015. New figures on unfunded public pension entitlements across Europe: concept, results and applications. Empirica 42 (4): 865-895. 
Kotlikoff, Laurence. 1992. Generational Accounting: Knowing Who Pays and Knowing When for What We Spend. New York (NY): The Free Press.

Lenze, David G. 2013. State and Local Government Defined Benefit Pension Plans: Estimates of Liabilities and Employer Normal Costs by State, 2000-2011. Working paper. Washington (D. C.): Bureau of Economic Analysis.

Mink, Raimund and Marta Rodríguez Vives (eds.). 2010. European Central Bank and Eurostat Workshop on Pensions, 29-30 April 2009. Frankfurt am Main: European Central Bank.

Müller, Christoph, Bernd Raffelhüschen and Olaf Weddige. 2009. Pension obligations of government employer pension schemes and social security pension schemes established in EU countries. Studie im Auftrag der Europäischen Zentralbank. Freiburg: Forschungszentrums Generationenverträge, Universität Freiburg.

Munnell, Alicia H., Jean-Pierre Aubry and Mark Cafarelli. 2014. The Funding Of State And Local Pensions: 2013-2017. Boston (MA): Center for Retirement Research at Boston College.

Novy-Marx, Robert and Joshua D. Rauh. 2011. Public Pension Liabilities: How Big Are They and What Are They Worth? Journal of Finance 66 (4): 1207-1246.

OECD. 2017a. Pensions at a Glance 2017: OECD and G20 Indicators. Paris: OECD Publishing.

OECD. 2017b. Health at a Glance 2017: OECD Indicators. Paris: OECD Publishing.

OECD. 2019. The OECD Collection of Annual Estimates of Pension Entitlements in Social Insurance: First Main Findings, Working Party on Financial Statistics, COM/SDD/DAF(2019) 4. Paris: OECD. http://www.oecd.org/officialdocuments/publicdisplaydocumentpdf/?cote= COM/SDD/DAF(2019)4\&docLanguage=En. Accessed: 1 January 2021.

OECD. 2020a. Guidelines for the OECD Table on Social Insurance Pension Schemes (Table 2900). https://www.oecd.org/statistics/datacollection/Guidelines\%20on\%20the\%20OECD\%20table\%20 on\%20social\%20insurance\%20pension\%20schemes.pdf. Accessed: 1 January 2021.

OECD. 2020b. Notes to OECD Pension Metadata Sheet. OECD: Paris. https://www.oecd.org/sdd/ na/OECD-Social-Pension-Scheme-Metadata-United-States.pdf. Accessed: 3 January 2021.

PKV (Verband der Privaten Krankenversicherung). (various years) Zahlenbericht der Privaten Krankenversicherung. Cologne: Verband der Privaten Krankenversicherung e.V.

Raffelhüschen, Bernd. 1999. Generational Accounting in Europe. American Economic Review: Papers and Proceedings 89 (2): 167-170.

Reinhart, Carmen M. and Kenneth S. Rogoff. 2009. This Time is Different: Eight Centuries of Financial Folly. Princeton (NJ): Princeton University Press.

Reinsdorf, Marshall, David Lenze and Dylan Rassier. 2014. Bringing Actuarial Measures of Defined Benefit Pensions into the U.S. National Accounts. Paper prepared for the IARIW 33rd General Conference, Rotterdam, the Netherlands. August 2014. http://www.iariw.org/papers/ 2014/ReinsdorfPaper.pdf. Accessed: 23 May 2019.

SVR (German Council of Economic Experts). 2011. Herausforderungen des demografischen Wandels - Expertise im Auftrag der Bundesregierung. Occasional Report. Wiesbaden: Statistisches Bundesamt.

Shiller, Robert J. and Mark J. Kamstra. 2010. Trills Instead of T-Bills: It's Time to Replace Part of Government Debt with Shares in GDP. The Economists' Voice 7 (3): Article 5.

Stefanescu, Irina and Ivan Vidangos. 2014. Introducing Actuarial Liabilities and Funding Status of Defined-Benefit Pensions in the U.S. Financial Accounts. Finance and Economics Discussion Series Note. 2014-10-31. Washington (D.C.): Board of Governors of the Federal Reserve System.

Uhlig, Harald and Mathias Trabandt. 2011. The Laffer Curve Revisited. Journal of Monetary Economics 58: 305-327. 
van de Ven, Peter and Daniele Fano (eds.). 2017. Understanding Financial Accounts. Paris: OECD Publishing.

Werding, Martin. 2011. Demographie und öffentliche Haushalte - Simulationen zur langfristigen Tragfähigkeit der gesamtstaatlichen Finanzpolitik in Deutschland, Arbeitspapier 03/2011 des Sachverständigenrats zur Begutachtung der gesamtwirtschaftlichen Entwicklung, Wiesbaden: Statistisches Bundesamt.

World Bank. 2019. DataBank - World Development Indicators. https://databank.world-bank.org/ data/home.aspx. Accessed: January-June 2019.

Open Access This chapter is licensed under the terms of the Creative Commons Attribution 4.0 International License (http://creativecommons.org/licenses/by/4.0/), which permits use, sharing, adaptation, distribution and reproduction in any medium or format, as long as you give appropriate credit to the original author(s) and the source, provide a link to the Creative Commons license and indicate if changes were made.

The images or other third party material in this chapter are included in the chapter's Creative Commons license, unless indicated otherwise in a credit line to the material. If material is not included in the chapter's Creative Commons license and your intended use is not permitted by statutory regulation or exceeds the permitted use, you will need to obtain permission directly from the copyright holder.

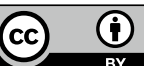

